Journal of the Scientific Agricultural Society of Finland Vol. 53: 239-268, 1981

Maataloustieteellinen Aikakauskirja

\title{
REQUIREMENT FOR MAGNESIUM FERTILIZATION IN FINLAND
}

Selostus: Magnesiumlannoituksen tarve Suomessa.

\author{
RAILI JOKINEN \\ Department of Agricultural Chemistry \\ University of Helsinki \\ 00710 Helsinki 71, Finland
}

ACADEMIC DISSERTATION

To be presented, with the permission of the Faculty of Argiculture and Forestry of the University of Helsinki, for public criticism in Auditorium XIV on December 18, 1981, at 12 o'clock. 


\section{Preface}

This summary of a number of different studies has been prepared at the Department of Agricultural Chemistry, University of Helsinki. The incubation experiment dealt with in the studies has also been carried out at the same department. I would like to express my sincere gratitude to Professor Armi Kaila, Head of the Department of Agricultural Chemistry, for the support she has given me over the years and for providing advice concerning the construction of the summary, for reading the paper and for much valuable criticism.

I am very grateful to Docent Johan Korkman, Agr. Dr., and Docent Antti Jaakkola, Agr. Dr., for reading my paper and for offering considerable constructive advice.

The field and pot experiments were carried out, during the years 1970 to 1976, at the Institute of Agricultural Chemistry and Physics, Agricultural Research Centre, while I was working there as a researcher. I am indebted to the Heads of the Institute, from 1970 to 1979, for their extremely positive attitude towards my work. Furthermore, I would like to thank the whole staff of the Institute, without mentioning anyone in particular, for their considerable assistance in helping to make my work a success. I am also grateful to the Head and the staff of some of the experimental stations of the Agricultural Research Centre, for carrying out the field experiments.

At the Department of Agricultural Chemistry, University of Helsinki, Miss Kaija Tuominen has skilfully assisted me in many tasks.

I am indebted to Mrs. Hilkka Tähtinen, Agr. Lic., and Mrs. Liisa Mattila, M. Sc., for their advice and help in the statistical treatment of the results.

The summary has been translated into English by Mr. John Derome, M. Sc., and I would like to thank him for his good and expert work.

The Foundation for Research of Kemira Oy has kindly provided financial support for my studies, for which I am exceedingly grateful.

I will be ever-grateful to my husband and daughter for their unflinching support throughout the course of these studies and for even giving up some of their spare time to enable me to carry out my research work.

Finally, I would like to thank the Scientific Agricultural Society of Finland for accepting my paper in its series of publications.

Helsinki, September 1981

Raili Jokinen 


\section{CONTENTS}

Abstract

INTRODUCTION

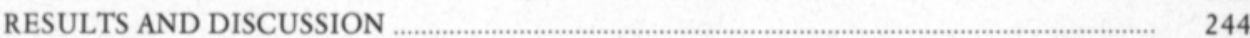

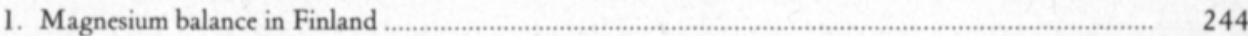

1.1. Magnesium input in fertilizers ......................................................................... 244

1.2. Magnesium input from liming agents ................................................................ 145

1.3. Magnesium in manure ……....................................................................... 246

1.4. Deposition of magnesium ................................................................................... 246

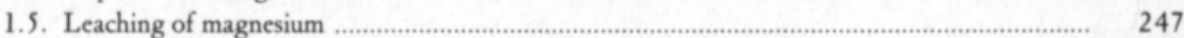

1.6. Magnesium removed in yields …….................................................................. 248

1.7. Magnesium balance of the soil .............................................................................. 249

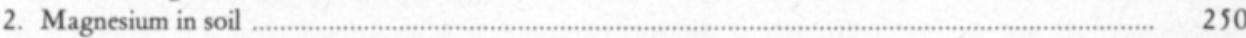

2.1. Magnesium content of soil in Finland ……...................................................... 250

2.2. Extraction of the magnesium available to plants ……................................................. 250

2.3. Effect of liming on the magnesium available to plants .................................................... 251

2.4. Effect of the amount of plant available magnesium in soil on the quantity and nutrient contents of the yields

3. Effect of nitrogen and potassium fertilizer levels on the quantity and nutrient contents of the yields ... 253

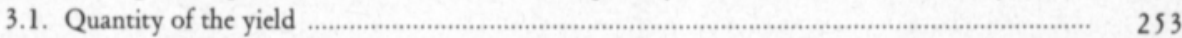

3.2. Uptake of magnesium ……................................................................................... 253

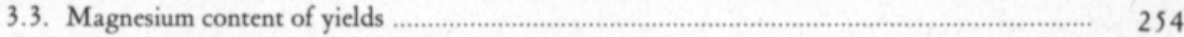

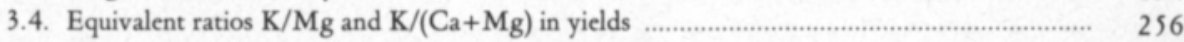

4. Determination of requirement for magnesium fertilization ........................................................ $\quad 256$

4.1. Ammonium acetate extractable magnesium in the soil .................................................. 257

4.2. Effect of liming on the extractability of fertilizer magnesium in the soil .................................. 257

4.3. Effect of magnesium fertilization on the yield and magnesium uptake ..................................... $\quad 257$

4.4. Apparent recovery of fertilizer magnesium ………………………..................... 259

4.5. Effect of magnesium fertilization on the nutrient contents of yields .................................... 259

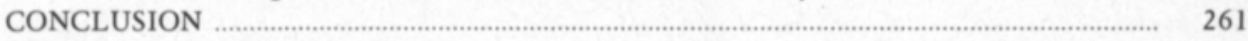

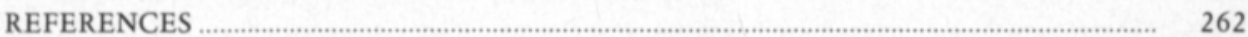

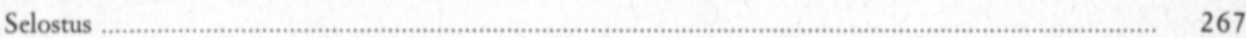


Abstract: More magnesium, on average, is removed annually from agricultural soils in Finland in yields (10 $\mathrm{kg} / \mathrm{ha})$ and through leaching $(20 \mathrm{~kg} / \mathrm{ha})$ than is replaced as fertilizers $(4 \mathrm{~kg} / \mathrm{ha})$, manure $(7 \mathrm{~kg} / \mathrm{ha})$ and as wet or dry depositions from the atmosphere $(1 \mathrm{~kg} / \mathrm{ha})$. The amount of magnesium which is applied in assosiation with liming agents (at the most $25 \mathrm{~kg} / \mathrm{ha}$ ) has a decisie effect on the magnesium balance of the soils, although liming itself reduces those magnesium reserves of the soil which are extractable in neutral ammonium acetate $(1 \mathrm{M})$ or in calcium chloride $(0,01 \mathrm{M})$.

The effect of two amounts of nitrogen and potassium fertilizers on the spring cereal and cultivated ley yields, on the magnesium uptake and nutrient contents of the yields, and the effect of liming on the magnesium status of the soil was studied using field, pot and incubation experiments in order to gain an estimate of requirement for magnesium fertilization. The results obtained with magnesium sulphate fertilizer in the same experiments were also used as an indicator of requirement for magnesium fertilization.

The ammonium acetate ( $1 \mathrm{M}, \mathrm{pH} 7)$ extractable magnesium in the soil appeared to be the most important source of magnesium for the plants and the best indicator of requirement for magnesium fertilization. For the intensive cultivation of grassland crops, the soil should contain about $15 \mathrm{mg} / 100 \mathrm{~g}$ of this type of magnesium. In pot experiments, the plants took up only small amounts of not extractable magnesium.

Increasing the nitrogen fertilizer dosage (pot experiments, 4,51 soil: $\mathrm{N}_{1}=1500 \mathrm{mg}, \mathrm{N}_{2}=3000 \mathrm{mg}$ per year, field experiments: $N_{1}=50 \mathrm{~kg} / \mathrm{ha}, \mathrm{N}_{2}=100 \mathrm{~kg} / \mathrm{ha} \mathrm{N}$ per year) generally brought about an increase in the magnesium uptake and in the magnesium content of the grasses. When the experiments were carried out using coarse mineral soils, the magnesium uptake and magnesium content of the plants decreased during the second and third year as the amount of nitrogen fertilizer increased. This was caused by the low magnesium content of the soil (pot experiments: below $12 \mathrm{mg} / 100 \mathrm{~g}$ soil in neutral ammonium acetate extractable magnesium, field experiments: below $100 \mathrm{mg} / 1$ soil in acid ammonium acetate extractable magnesium). In these soils, magnesium fertilization (200 mg Mg for 4,51 soil per year or $57 \mathrm{~kg} / \mathrm{ha}$ per year) appeared to have a positive effect on the supply of magnesium to the plants. The heavy clay and sandy clays used in the pot experiment did not require magnesium fertilization. The magnesium in silty clays, which contain a high proportion of the silt fraction $(0,02-0,2 \mathrm{~mm})$, may be liberated too slowly for intensively cultivated grasses and it may be necessary to give additional magnesium as fertilizer.

Increasing the potassium fertilizer level from $60 \mathrm{~kg} / \mathrm{ha}$ to $240 \mathrm{~kg} / \mathrm{ha} \mathrm{K}$ per year significantly decreased the magnesium content of the plants. Judging by the quality of the crops, a high potassium fertilizer level appeared to increase the requirement for magnesium fertilization. In the case of muddy very finesand the yield and magnesium uptake of timothy decreased with an increase in the amount of potassium applied.

Liming $\left(90,180\right.$ or $360 \mathrm{mg} / 100 \mathrm{~g}$ soil $\mathrm{Ca}$ as $\left.\mathrm{CaCO}_{3}\right)$ decreased the amount of neutral ammonium acetate extractable magnesium, in seven mineral soils out of nine, by $2-24 \%$ in comparison to the magnesium content of unlimed soils. Part of the fertilizer magnesium became not extractable, too.

\section{Introduction}

Magnesium has a number of important functions in plants. As the central atom in the chlorophyll molecule it participates in the metabolism of plants. Approximately one quarter of the magnesium occurring in plants is bound in chlorophyll (MICHAEL 1941, NEALES 1956). Most of the magnesium found in 
plants acts as a coenzyme for a number of different enzymes associated with, for example, carbohydrate, protein and lipid metabolism and respiration (NASON 1958).

The magnesium content of monocotyledons is about one third that of dicotyledons (DRAKE et al. 1951, RAININKO 1968, JOKINEN 1969 a). Measures aimed at increasing the magnesium content of monocotyledonous plants are important with respect to improving the quality of fodder for livestock.

Nitrogen fertilization of field crops increased in Finland at the beginning of the 1970 's as a result of the low price of fertilizers. Heavy fertilization with ammonium nitrate limestone, which contains magnesium, increased the magnesium content of grassland crops (RAININKO 1968, RINNE et al. 1974). The studies carried out by SALONEN et al. (1962) did not give any information about whether the magnesium reserves in the soil under intensive grassland cultivation are sufficient in Finland, owing to the fact that soil analyses were not included, similarly the studies performed by SILLANPÄÄ and RINNE (1975) because of the magnesium content of the nitrogen fertilizer.

Rather early on, researchers such as LOEWING (1928), van ITALLIE (1937) and DRAKE and SCARSETH (1939), showed that potassium fertilization or a high potassium content of the soil had a negative effect on the magnesium content and magnesium uptake of plants. Potassium fertilization plays an important role in the fertilization of grassland crops, because heavy nitrogen fertilization increases the utilization of the soil's own potassium reserves (JOY et al. 1973), while on the other hand the potassium content of the crop can easily increase to too high a level (TÄHTINEN 1979). A possible requirement of magnesium fertilization may be associated with the application of large doses of nitrogen and potassium.

One of the factors limiting plant production in Finland appears to be soil acidity, since the average $\mathrm{pH}\left(\mathrm{H}_{2} \mathrm{O}\right)$ value of agricultural soils is $5,55 \pm 0,48$ (SIPPOLA and TARES 1978). When the acidity of the soil is decreased through liming, the solubility of different nutrients in the soil changes. Only a few studies have been carried out in Finland into the effect of liming or different types of lime on the magnesium status of the soil and magnesium uptake of plants (e.g. KERÄNEN and JOKINEN 1964, KAILA 1974, JAAKKOLA and JOKINEN 1980).

HEINONEN (1956) found that magnesium fertilization did not significantly increase the size of the potato yield, and he estimated that the requirement for magnesium fertilization in Finland is rather small. In the field experiments carried out by KERÄNEN and TAINIO (1967) and JOKINEN (1971), magnesium fertilization had a positive effect on the yields obtained on magnesium deficient soils.

Changes in the proportion of magnesium and potassium out of the cation exchange capacity of the soil explained only a small part of the variation in the magnesium content of timothy and clover (JOKINEN $1969 \mathrm{~b}$ ). The type and amount of nutrients given as fertilizers may have a greater effect on the magnesium content and magnesium uptake by plants than the nutrient status of the soil.

The aim of these studies was to determine the effect of nitrogen, potassium and calcium, added to the soil as fertilizer, on the magnesium uptake, nutrient contents and ratios of spring cereals, timothy or ryegrass, and on the nutrient status of the soil. An attempt has also been made to estimate requirement for magnesium fertilization on the basis of the above- mentioned studies, of the results obtained with magnesium fertilization and of the magnesium balance of different soils. 
The results of these studies are presented in detail in the following publications: JOKINEN, R. 1977 a. Effect of added magnesium, potassium, lime and nitrogen on oats I. Yields. J. Scient. Agric. Soc. Finl. 49: 283-295.

- 1977 b. Effect of added magnesium, potassium, lime and nitrogen on oats II. Nutrient contents, cation ratios and magnesium uptake. J. Scient. Agric. Soc. Finl. 49: 296-314.

- 1978. The effect of magnesium fertilizing on spring cereal and cultivated ley yield and on soil nutrient contents at two potassium and nitrogen fertilizer levels. Ann. Agric. Fenn. 17: 192-204.

- 1979 a. The effect of magnesium, potassium and nitrogen fertilizers on the contents and ratios of nutrients in spring cereals and grassland crops. Ann. Agric. Fenn. 18: 188-202.

- $1979 \mathrm{~b}$. The effect of magnesium, potassium and nitrogen fertilizers on the uptake of nutrients by spring cereals and cultivated grassland. Ann. Agric. Fenn. 18: 203-212.

- 1981 a. Soil magnesium and fertilizer magnesium uptake by ryegrass on nine mineral soils at two ammonium nitrate levels I. Magnesium uptake. Ann. Agric. Fenn. 20: 231-243

- $1981 \mathrm{~b}$. Soil magnesium and fertilizer magnesium uptake by ryegrass on nine mineral soils at two ammonium nitrate levels II. Magnesium content of soils. Ann. Agric. Fenn. 20: 244-252

- 1981 c. Effect of liming on the magnesium status of some mineral soils and on the fate of fertilizer magnesium. J. Scient. Agric. Soc. Finl. 53: 126-137.

Results and discussion

1. Magnesium balance in Finland

\subsection{Magnesium input in fertilizers}

Ammonium nitrate limestone, which contains 2,2\% magnesium, has been manufactured in Finland since the 1950's. Magnesium has been added to multinutrient fertilizers since the beginning of the 1970's. According to information supplied by the fertilizer manufacturer (Kemira Ltd), fertilizers at the present time in Finland contain from 0,1 to $2,5 \%$ magnesium. Either magnesium sulphate heptahydrate $(9,7 \% \mathrm{Mg})$ or anhydrous magnesium sulphate $(19 \% \mathrm{Mg})$ is used as magnesium fertilizer.

According to data collected by the Marketing Research Institute of the Pellervo Society and published by Kemira Ltd, about one third of the magnesium given in fertilizers $(2,3 \mathrm{~kg} / \mathrm{ha}$, on average) was derived from multi-nutrient fertilizers and two thirds from nitrogen fertilizers (Table 1) during the period 1. 7. 1969-30. 6. 1970 (ANON. 1980 a). During the corresponding period in 1979-80, the average figure was $4,1 \mathrm{~kg} / \mathrm{ha}$ magnesium, the proportion of magnesium derived from multinutrient fertilizers being $60 \%$. In Finland, the amount of magnesium removed in the cereal grains or in the potato yields is equivalent to the magnesium which is added annually in fertilizers. 
Table 1. Amounts of magnesium (1000 t) in fertilizers sold for agricultural use during the fiscal periods from $1969 / 70$ to $1979 / 80$, the proportion (\%) of different types of fertilizers out of the total sales of magnesium, and the average amount of magnesium $(\mathrm{kg} / \mathrm{ha})$ applied to agricultural area annually (ANON. 1980 b).

\begin{tabular}{lccccc}
\hline & & \multicolumn{2}{c}{ Proportion of different fertilizer types, \% } & \\
\cline { 3 - 5 } $\begin{array}{l}\text { Fiscal } \\
\text { year }\end{array}$ & $\begin{array}{c}\text { Mg } \\
1000 \mathrm{t}\end{array}$ & $\begin{array}{l}\text { Nitrogen } \\
\text { fertilizers }\end{array}$ & $\begin{array}{c}\text { Multi- } \\
\text { nutrient } \\
\text { fertilizers }\end{array}$ & $\begin{array}{c}\text { Magnesium } \\
\text { sulphates }\end{array}$ & $\begin{array}{c}\mathrm{Mg} \\
\mathrm{kg} / \mathrm{ha}\end{array}$ \\
\hline $1969 / 70$ & 6,22 & 58 & 32 & 2 & 2,3 \\
$1970 / 71$ & 7,09 & 63 & 29 & 3 & 2,8 \\
$1971 / 72$ & 7,75 & 66 & 26 & 4 & 3,1 \\
$1972 / 73$ & 8,54 & 56 & 38 & 3 & 3,5 \\
$1973 / 74$ & 7,81 & 51 & 44 & 3 & 3,3 \\
$1974 / 75$ & 9,95 & 46 & 51 & 2 & 4,1 \\
$1975 / 76$ & 8,48 & 48 & 49 & 2 & 3,5 \\
$1976 / 77$ & 7,82 & 39 & 58 & 2 & 3,2 \\
$1977 / 78$ & 7,42 & 33 & 65 & 1 & 3,2 \\
$1978 / 79$ & 7,91 & 38 & 60 & 2 & 3,4 \\
$1979 / 80$ & 9,40 & 37 & 62 & 1 & 4,1 \\
\hline
\end{tabular}

According to the sales figures for fertilizers, about 17 times more potassium, and about 25 times more nitrogen $(\mathrm{kg} / \mathrm{ha})$ than magnesium was used in Finland during the fiscal period 1969-70. The corresponding figures for the period 1979-80 were 12 times (potassium) and 20 times (nitrogen).

\subsection{Magnesium input from liming agents}

All the liming agents used in Finland come from domestic quarries and mines. The magnesium content of the different deposits vary to a considerable extent.

According to data collected by the Liming Association (Exec. dir. Matti Suvanto, M.Sc., personal communication), a total of 429100 tons of different types of limestone were sold for agricultural purposes in 1972, and a total of 901000 tons in 1980 (Table 2). The average amount of limestone used on the total field area under cultivation was $390 \mathrm{~kg} / \mathrm{ha}$, in the latter year.

The proportion of dolomitic limestone 2 out of the total amount of liming agents sold was about $40 \%$ in 1976 and about $59 \%$ in 1980. The sales of dolomitic limestones and calcitic limestone containing magnesium accounted for more than $80 \%$ of the total sales of liming agents. The amount of magnesium added to the soil through liming has almost doubled in five years (1976-1980). In the favorable weather conditions in 1980, the average amount of magnesium added to fields in liming agents was about $25 \mathrm{~kg} / \mathrm{ha}$.

The most common level for single doses of limestones is about $5 \mathrm{t} / \mathrm{ha}$, representing magnesium dosages of $250 \mathrm{~kg}$ for the calcitic limestone containing magnesium, $400 \mathrm{~kg}$ for dolomitic limestone 2 and $550 \mathrm{~kg}$ for dolomitic limestone 1 , on average.

Slag from iron smelters $(6,5 \% \mathrm{Mg})$ and from steel industry $(1,5 \% \mathrm{Mg})$ are also used to some extent in Finland as ameliorating agents. However, slag is only used for this purpose in areas with steel works in the vicinity. 
Table 2. Sales of liming agents $(1000 \mathrm{t})$ in Finland and the amount of magnesium applied in different types of limestone (1 $000 \mathrm{t}$ and $\mathrm{kg} / \mathrm{ha}$ ) in the years 1972, 1976, 1979 and 1980 (Liming Assosiation 1981).

\begin{tabular}{|c|c|c|c|c|c|c|c|}
\hline \multirow[b]{2}{*}{ Year } & \multicolumn{5}{|c|}{ Sales of liming agents, $1000 \mathrm{t} / \mathrm{a}$} & \multirow[b]{2}{*}{$\begin{array}{c}\text { Magnesium } \\
\text { in liming } \\
\text { agent } \\
1000 \mathrm{t}\end{array}$} & \multirow[b]{2}{*}{$\begin{array}{c}\text { Magnesium } \\
\mathrm{kg} / \mathrm{ha}\end{array}$} \\
\hline & $\begin{array}{l}\text { Calcitic } \\
\text { limestones } \\
1 \text { and } 2\end{array}$ & $\begin{array}{l}\text { Mg-cont. } \\
\text { Calcitic } \\
\text { limestone } \\
(3-7 \% \mathrm{Mg})\end{array}$ & $\begin{array}{c}\text { Dolomitic } \\
\text { limestone } 2 \\
(7-10 \% \mathrm{Mg})(\end{array}$ & $\begin{array}{c}\text { Dolomitic } \\
\text { limestone } 1 \\
(>10 \% \mathrm{Mg})\end{array}$ & Total & & \\
\hline 1972 & 335,9 & - & 6,7 & 85,5 & 429,1 & 10,1 & 4 \\
\hline 1976 & 271,0 & 52,3 & 280,6 & 93,9 & 697,8 & 35,4 & 14 \\
\hline 1979 & 132,6 & 67,7 & 388,9 & 91,0 & 680,2 & 44,5 & 19 \\
\hline 1980 & 174,5 & 94,1 & 531,2 & 101,3 & 901,1 & 58,3 & 25 \\
\hline
\end{tabular}

\subsection{Magnesium in manure}

HOLMA (1981) has estimated that there are 18,9 mill. tons of manure annually available in Finland. The proportion of liquid manure out of the total amount of freshly-handled manure is about $18,5 \%$. The amount of manure applied annually to the total agricultural area is about $8 \mathrm{t} / \mathrm{ha}$, liquid manure accounting for $1,5 \mathrm{t} / \mathrm{ha}$.

The nutrient content of manure is affected by, for instance, the type of animal and type of feed stuff used. According to KERÄNEN (1966), cattle manure from cow stables contains magnesium $1 \mathrm{~kg} / \mathrm{t}$ fresh matter $(4,9 \mathrm{~kg} / \mathrm{t}$ dry-matter $)$. The average magnesium content of liquid cattle manure, according to KÄHÄRI (1974), is $4,7 \pm 0,9 \mathrm{~kg} / \mathrm{t}$ dry-matter and for liquid pig manure $7,1 \pm 1,3 \mathrm{~kg} / \mathrm{t}$. As the average water content of liquid manure is $93 \%$, the magnesium content of fresh liquid cattle manure appears to be about $0,3 \mathrm{~kg} / \mathrm{t}$ and for liquid pig manure $0,5 \mathrm{~kg} / \mathrm{t}$. About $7 \mathrm{~kg}$ of magnesium are added annually in manures per hectare.

It is recommended that about $20 \mathrm{t} / \mathrm{ha}$ of solid manure or $50 \mathrm{~m}^{3} / \mathrm{ha}$ of liquid manure should be applied at any one time. These amounts of manure contain $20 \mathrm{~kg}$ of magnesium for cattle manure and 16 or $25 \mathrm{~kg}$ for liquid cattle or pig manure, respectively.

The sludge produced annually in sewage plants amounts to about 120000 tons dry-matter in Finland. Only a small part of this sludge is used in agriculture, for instance in 1980 about $30 \%$ (Heikki Latostenmaa, M. Sc., National Board of Waters, personal communication). The average magnesium content of sludge is 10 $\mathrm{kg} / \mathrm{t}$ dry-matter, although it varies considerably (ANON. 1976).

\subsection{Depositions of magnesium}

According to JØRGENSEN (1978), the amount of magnesium derived from wet and dry depositions in Denmark is $2,9 \mathrm{~kg} / \mathrm{ha}$. WIKLANDER (1970) reported that the magnesium content of rainfall near Uppsala in Sweden is $0,15 \mathrm{mg} / \mathrm{l}$. A total of about $1 \mathrm{~kg} / \mathrm{ha}$ magnesium is deposited through rainfall $(600 \mathrm{~mm})$. According to LÅG (1969), the amount of magnesium deposited through rainfall during the period $1955-62$ in four places in Norway varied from $0,5-17,3 \mathrm{~kg} / \mathrm{ha}$.

The amount of nutrients derived from wet and dry depositions has been studied in Finland since 1971 by the National Board of Waters. The project covers the whole of the country and samples are taken at about 50 different localities throughout the year. Data for different years and different sampling points since 
Table 3. Amounts of magnesium ( $\mathrm{kg} / \mathrm{ha}$ per year) added to soil as wet and dry depositions during the period 1972-1977 (mean of 50 observation points) and at 10 observation points in different parts of Finland during the same period (JÄRVINEN and HAAPALA 1980).

\begin{tabular}{llll}
\hline Year & $\begin{array}{l}\mathrm{Mg} \\
\mathrm{kg} / \mathrm{ha}\end{array}$ & $\begin{array}{l}\text { Observation } \\
\text { point } \\
\text { (Latitude North) }\end{array}$ & $\begin{array}{l}\mathrm{Mg} \\
\mathrm{kg} / \mathrm{ha} \\
\text { per year }\end{array}$ \\
\hline 1972 & $0,58^{\mathrm{a}}$ & Tvärminne $\left(59^{\circ} 51^{\prime}\right)$ & $1,20^{\mathrm{d}}$ \\
1973 & $0,84^{\mathrm{c}}$ & Jokioinen $\left(60^{\circ} 49^{\circ}\right)$ & $0,74^{\mathrm{bc}}$ \\
1974 & $1,07^{\mathrm{d}}$ & Jämijärvi $\left(61^{\circ} 44^{\prime}\right)$ & $0,90^{\mathrm{c}}$ \\
1975 & $0,78^{\mathrm{b}}$ & Punkaharju $\left(61^{\circ} 48^{\prime}\right)$ & $0,76^{\mathrm{bc}}$ \\
1976 & $0,60^{\mathrm{ab}}$ & Laukaa $\left(62^{\circ} 32^{\prime}\right)$ & $0,86^{\mathrm{bc}}$ \\
1977 & $0,72^{\mathrm{abc}}$ & Ylistaro $\left(62^{\circ} 56^{\prime}\right)$ & $0,62^{\mathrm{ab}}$ \\
$\begin{array}{l}\text { Mean } \pm \text { sd } \\
1972-1977\end{array}$ & $0,77 \pm 0,24$ & Pyhäntä $\left(63^{\circ} 56^{\prime}\right)$ & $0,70^{\mathrm{ab}}$ \\
& & Pudasjärvi $\left(65^{\circ} 22^{\prime}\right)$ & $0,90^{\mathrm{c}}$ \\
& & Sodankylä $\left(67^{\circ} 22^{\prime}\right)$ & $0,48^{\mathrm{a}}$ \\
\hline
\end{tabular}

Means followed by a common letter do not differ at $P=0,05$. Means of the different years and of different observation points were tested separately by Duncan's new multiple range test.

1972 have been collected and published by JÄRVINEN and HAAPALA (1980). On the basis of the whole material, the amount of magnesium deposited in different years varied from 0,58 to $1,07 \mathrm{~kg} / \mathrm{ha}$ (Table 3 ). The magnesium depositions during the wet year of 1974 were considerably greater than those during the dryish year of 1972. During the period 1972-1977, the mean annual deposition amounted to $0,77 \pm 0,24 \mathrm{~kg} / \mathrm{ha}$.

The results for ten sampling points situated in different parts of the country during the period 1972-1977 show that magnesium deposition in North Finland is only about half that in Central Finland and about one third that along the southern coast of Finland (Table 3).

Rainfall samples were taken by the method presented by SOVERI (1976) at the Department of Agricultural Chemisty, University of Helsinki, in Viikki in summer 1981. The mean deposition of magnesium was found to be about $0,4 \mathrm{~kg} / \mathrm{ha}$ per month. Near Helsinki magnesium deposition seemed to be much higher than in the rural districts.

\subsection{Leaching of magnesium}

WIKLANDER (1970) estimated that the amount of water leaching through the soil into field drains in Sweden every year is equivalent to $200 \mathrm{~mm}$ of rainfall. The amount of cations removed from the soil in this water depends, for instance, on the $\mathrm{pH}$ of the soil or water, the particle size distribution of the soil, fertilization, liming and the types of vegetation cover.

In studies carried out on the cation composition of field drain water (WIKLANDER and HALLGREN 1971) or the composition of water draining through lysimeters (LOW and ARMITAGE 1970, WEISE 1972, HARTIKAINEN $1978)$, it has been found that the amount $(\mathrm{mg} / \mathrm{l}, \mathrm{kg} / \mathrm{ha})$ of calcium leached is greater than that for magnesium. According to HARTIKAINEN (1978), the relative amounts of magnesium leached, out of the total amount of exchangeable cations in the soil, were almost as great as those for calcium. 
HENRIKSEN (1970) has estimated that the amount of magnesium leached annually in Denmark is $15 \mathrm{~kg} / \mathrm{ha}(4-35 \mathrm{~kg} / \mathrm{ha})$, WIKLANDER and HALLGREN (1971) have reported $24 \mathrm{~kg} / \mathrm{ha}(8-30 \mathrm{~kg} / \mathrm{ha})$ for Sweden, and WEISE (1972) 11 $25 \mathrm{~kg} / \mathrm{ha}$ for Germany. In Finland the amount of magnesium in the water flowing into field drains underlying heavy clay has been estimated to be about $18 \mathrm{~kg} / \mathrm{ha}$ and in the surface water about $4 \mathrm{~kg} / \mathrm{ha}$ (Docent Antti Jaakkola, Agric. Res. Centre, personal communication), calculated as the mean for a four-year period. In this field set-up designed for carrying out leaching experiments, the area was left fallow for one year, barley was grown for two years and winter wheat for one year. The magnesium content of water leaching through sandy clay, finesand or sand soil in laboratory experiments varied from 8 to $18 \mathrm{mg} / 1$ soil, corresponding to $16-36 \mathrm{~kg}$ magnesium per hectar (HARTIKAINEN 1978). The mean value for leaching losses of magnesium in Finland may be $15-20 \mathrm{~kg} / \mathrm{ha}$ per year.

Water with a low pH value was found in HARTIKAINEN's (1978) study to greatly increase leaching of magnesium. The median $\mathrm{pH}$ value of rainwater in Finland is 4,6 (JÄRVINEN and HAAPALA 1980).

The type of vegetation cover considerably decreases the leaching of magnesium. In lysimeter experiments carried out at Jealot Hills in England, magnesium equivalent to $72 \mathrm{~kg} / \mathrm{ha}$ was leached from a lysimeter left fallow, and $41 \mathrm{~kg} / \mathrm{ha}$ from a lysimeter where grasses were growing (LOW and ARMITAGE 1970).

\subsection{Magnesium removed in yields}

In an experiment carried out by HUOKUNA and LAPIOLAHTI (1980), meadow fescue harvested for silage removed $16-20 \mathrm{~kg} / \mathrm{ha}$ of magnesium annually. The timothy yield harvested as dry hay removed, on the average, $6 \mathrm{~kg} / \mathrm{ha}$ of magnesium from the soil and the grain yield of spring cereals $3,5 \mathrm{~kg} / \mathrm{ha}$ (JOKINEN 1979 b).

The proportion of the field area under cereals out of the total area in agricultural production in Finland in 1981 was about $52 \%$, the area under grasses about $40 \%$ and the rest, about $8 \%$, used for root crops, oilcrops etc. (National Board of Agriculture, personal communication).

The amounts of magnesium taken up by different plants (Table 4) was calculated on the basis of the mean magnesium contents of Swedish agricultural crop yields presented by SVANBERG (1971) and the mean yields obtained in Finland during the period 1975-1979 (ANON. 1980 b). It was assumed that the straw of cereals, the stalks of potatoes and oilcrops and the tops of root crops are ploughed back into the soil. The magnesium removed in cereal yields is of almost the same magnitude as that found in field experiments (JOKINEN 1979 b), but considerably smaller than the figures quoted by MENGEL (1979 p. 283). The amounts of magnesium removed in root crops and silage crops appear to be rather small since the mean size of the yields is low. The variation in the size of the yield of these crops in different parts of the country and in different years is extremely large.

The average amount of magnesium removed in the yields is $10 \mathrm{~kg} / \mathrm{ha}$ assuming that the magnesium removed in cereal yields ( 1,2 mill. ha) amounts to $5 \mathrm{~kg} / \mathrm{ha}$ and in other types of crop yields $(1,1$, mill. ha) to $15 \mathrm{~kg} / \mathrm{ha}$. Magnesium is also added to the soil in seed. The amounts added in potato $(0,6 \mathrm{~kg} / \mathrm{ha})$, pea $(0,4 \mathrm{~kg} / \mathrm{ha})$ and cereal $(0,3 \mathrm{~kg} / \mathrm{ha})$ cultivation are greater, on the average, than in the cultivation of other types of crops. 
Table 4. The mean yield of different crops ( $t / h a, A N O N .1980$ a), the magnesium content of agricultural yields $(\mathrm{kg} / \mathrm{t} \mathrm{Mg}$ in air-dry state, SVANBERG 1971$)$ and the amount of magnesium $(\mathrm{kg} / \mathrm{ha})$ removed in the yields calculated from the above datas and according to MENGEL $\left(1979^{1}\right)$.

\begin{tabular}{|c|c|c|c|c|c|}
\hline & $\begin{array}{l}\text { Yield } \\
\text { t/ha }\end{array}$ & $\begin{array}{c}\text { Moisture } \\
\%\end{array}$ & $\begin{array}{l}\mathrm{Mg} \\
\mathrm{kg} / \mathrm{t}\end{array}$ & $\begin{array}{l}\mathrm{Mg} \\
\mathrm{kg} / \mathrm{ha}\end{array}$ & $\begin{array}{l}\left.\mathrm{Mg}^{1}\right) \\
\mathrm{kg} / \mathrm{ha}\end{array}$ \\
\hline Winter wheat, grain & 2,7 & 16 & $\begin{array}{l}1,2 \\
0.6\end{array}$ & 3,2 & 18 \\
\hline $\begin{array}{l}\text { Spring wheat, grain } \\
\text { straw }\end{array}$ & 2,4 & 16 & $\begin{array}{l}1,2 \\
0,6\end{array}$ & 2,9 & 15 \\
\hline $\begin{array}{l}\text { Rye, grain } \\
\text { straw }\end{array}$ & 2,1 & 16 & $\begin{array}{l}1,2 \\
0,6\end{array}$ & 2,5 & 15 \\
\hline $\begin{array}{r}\text { Barley, grain } \\
\text { straw }\end{array}$ & 2,7 & 16 & $\begin{array}{l}1,2 \\
0,6\end{array}$ & 3,2 & 13 \\
\hline $\begin{array}{l}\text { Oats, grain } \\
\text { straw }\end{array}$ & 2,6 & 16 & $\begin{array}{l}1,2 \\
0,7\end{array}$ & 3,1 & 12 \\
\hline $\begin{array}{r}\text { Pea, } \\
\text { seed } \\
\text { stalk }\end{array}$ & 2,1 & 16 & $\begin{array}{l}1,8 \\
1,2\end{array}$ & 3,8 & \\
\hline $\begin{array}{r}\text { Turnip rape, seed } \\
\text { stalk }\end{array}$ & 1,5 & 9 & $\begin{array}{l}2,5 \\
1,2\end{array}$ & 3,9 & 27 \\
\hline $\begin{array}{c}\text { Ley, dry hay, timothy } \\
\text { clover }\end{array}$ & $\begin{array}{l}3,8 \\
3,8\end{array}$ & $\begin{array}{l}15 \\
15\end{array}$ & $\begin{array}{l}1,3 \\
3,4\end{array}$ & $\begin{array}{r}5,0 \\
13,0\end{array}$ & \\
\hline silage & 17,5 & 80 & 0,4 & 7,0 & 24 \\
\hline $\begin{array}{c}\text { Potato, roots } \\
\text { tops }\end{array}$ & 16,1 & $\begin{array}{l}79 \\
82\end{array}$ & $\begin{array}{l}0,2 \\
0,6\end{array}$ & 3,2 & 9 \\
\hline $\begin{array}{r}\text { Sugar beet, roots } \\
\text { tops }\end{array}$ & 22,3 & $\begin{array}{l}76 \\
80\end{array}$ & $\begin{array}{l}0,4 \\
0,9\end{array}$ & 8,9 & 45 \\
\hline
\end{tabular}

\subsection{Magnesium balance of the soil}

In the 1950's, the magnesium balance was estimated to be on the negative side in acidic mineral soils in Finland (HEINONEN 1956). However, the mean magnesium balance for the whole country was not found to be showing a loss. HENRIKSEN (1970) has calculated that the magnesium deficit on farms without livestock in Denmark is $20 \mathrm{~kg} / \mathrm{ha}$ and on farms with livestock $5 \mathrm{~kg} / \mathrm{ha}$. WIKLANDER (1970) has also found that the magnesium deficit is large on a number of different types of soil in Sweden.

In Finland, about $12 \mathrm{~kg} / \mathrm{ha}$ of magnesium is added to the soil every year through manure, fertilizers and depositions. As the amount of magnesium removed in yields and through leaching appears to be about $25-30 \mathrm{~kg} / \mathrm{ha}$, the annual deficit of magnesium is about $13-18 \mathrm{~kg} / \mathrm{ha}$. The magnesium added to the soil through liming agents, about $25 \mathrm{~kg} / \mathrm{ha}$, would put the balance on the positive side. However, as part of the magnesium in liming materials, as well as some of the magnesium in the soil, are converted into a form not extractable in ammonium acetate when the $\mathrm{pH}\left(\mathrm{CaCl}_{2}\right)$ is close to 6,0 , the magnesium balance may continue to show a deficit despite of liming.

The magnesium balance of a farm with livestock would appear to show a yearly deficit of $5 \mathrm{~kg} / \mathrm{ha}$ when the recommended amounts of manure are used, if the fields are not limed. The magnesium deficit on farms without livestock appears to be 15$25 \mathrm{~kg} / \mathrm{ha}$. The use of liming agents containing magnesium at intervals of $5-10$ years makes the magnesium balance of the fields of both types of farm positive. 


\subsection{Magnesium content of soil in Finland}

The most important magnesium-containing silicate minerals to be found in Finland are pyroxenes, amphiboles, micas and clay minerals containing magnesium. The most important of the carbonate minerals is dolomite.

In silicate minerals, magnesium is tightly bound in the molecular structure and it is only released as a result of weathering. Pyroxenes are more susceptible to weathering than amphiboles and micas. Quartz and feldspars, which do not contain magnesium, are resistant to weathering. For this reason, there is more magnesium in the fine fraction of sedimentary soils than in the coarse fraction (RANKAMA and SAHAMA 1966). According to SIPPOLA (1974), the mica content of the clay and silt fractions of Finnish subsoils best explained variations in the total magnesium of these fractions.

The total amount of magnesium in the topsoil of mineral soils in the southern half of Finland varies from $0,56 \pm 0,08 \%$ in sand and finesand soils to $1,53 \pm 0,19 \%$ in heavy clay soils (KAILA 1973). The total magnesium content in the subsoil is also the lowest in sand soils $(0,27 \pm 0,11 \%)$ and highest in heavy clay soils $(2,03 \pm 0,21 \%$, SIPPOLA 1974). The proportion of magnesium extractable in ammonium acetate ( $1 \mathrm{M}, \mathrm{pH} 7)$ out of the total amount of magnesium varies from $2,3 \pm 0,6 \%$ (sand and finesand soils) to $5,9 \pm 1,5 \%$ (heavy clay soils, KAILA 1973). The proportion of magnesium out of the effective cation exchange capacity is $9 \pm 2 \%$ in sand and finesand soils, $30 \pm 4 \%$ in heavy clay soils and between these values in other mineral soil types (KAILA 1972). The amount of magnesium extractable in ammonium acetate is, according to MARTTILA (1965), lower in Littorina clay soils $(2,0 \pm 1,7 \mathrm{me} / 100 \mathrm{~g}$ soil $)$ than in other clay soils $(4,8 \pm 4,3 \mathrm{me} / 100 \mathrm{~g}$ soil). The mean amount of magnesium extractable in ammonium acetate $(1 \mathrm{M}, \mathrm{pH} 7)$ is in sand and finesand soils $13 \pm 3 \mathrm{mg} / 100 \mathrm{~g}$, in silt soils $17 \pm 4 \mathrm{mg} / 100 \mathrm{~g}$, in sandy clays and silty clays $27 \pm 5 \mathrm{mg} / 100 \mathrm{~g}$ and in heavy clay soils $84 \pm 15 \mathrm{mg} / 100 \mathrm{~g}$ (KAILA 1973).

The particle size distribution has a considerable effect on the magnesium content of mineral soils. An increase in the proportion of the $<2 \mu \mathrm{m}$ fraction causes an increase in the total amount of magnesium in the topsoil ( $r=0,81^{* * *}$, KAILA $1973)$ and in the subsoil $\left(\mathrm{r}=0,89^{* * *}\right.$, SIPPOLA 1974). According to KAILA and RYTI $(1968 \mathrm{a})$, the total amounts of magnesium in the fractions $<2 \mu \mathrm{m}, 2-20 \mu \mathrm{m}$ and $20-200 \mu \mathrm{m}$ are $2,01 \pm 0,14 \%, 1,10 \pm 0,10 \%$ and $0,54 \pm 0,06 \%$ respectively. The corresponding amounts of ammonium acetate extractable magnesium are $71 \pm$ $28 \mathrm{mg} / 100 \mathrm{~g}, 16 \pm 6 \mathrm{mg} / 100 \mathrm{~g}$ and $5 \pm 1 \mathrm{mg} / 100 \mathrm{~g}$ soil.

Most of the magnesium present in the organic matter fraction of mineral soils is structurally bound and only a small portion of it can be extracted with ammonium acetate (ÅRESUND 1980).

\subsection{Extraction of the magnesium available to plants}

Potassium chloride ( $(\mathrm{M})$ ) was found to extract only about $78 \%$ of the magnesium extractable in ammonium acetate $(1 \mathrm{M}, \mathrm{pH} 7)$ in the case of acid muddy silt. The extractibility of potassium chloride in other soil types ranged from 82 to $96 \%$ (JOKINEN 1981b). In incubation experiments, potassium chloride extracted 
slightly less magnesium from acid silty clay, in addition to muddy silt, than ammonium acetate did (JOKINEN $1981 \mathrm{c}$ ).

The proportion of magnesium extractable in calcium chloride $(0,01 \mathrm{M})$, to that extractable in ammonium acetate, was below $60 \%$ in clay soils and varied from 70 to $100 \%$ in coarce mineral soils (JOKINEN $1981 \mathrm{~b}, 1981 \mathrm{c}$ ). The studies by WELTE et al. (1960) and FARINA et al. (1980)gave corresponding results. Owing to weak solution and their large size, $\mathrm{Ca}^{2+}$ ions are perhaps not as effective as the smaller $\mathrm{NH}_{4}{ }^{+}$and $\mathrm{K}^{+}$ions in displacing the magnesium ions.

The magnesium extractable in calcium chloride may prove to be that portion of the soil magnesium which is readily available to plants (SCHACHTSCHABEL 1954). In pot experiments, the cumulative uptake of magnesium by ryegrass over a period lasting for a number of years was greater than the amount by which the magnesium extractable in calcium chloride dereased during the course of the experiment (JOKINEN $1981 \mathrm{~b}$ ). The magnesium uptake of ryegrass and the change (initial final) in the ammonium acetate extractable magnesium in the soil were closely correlated with each other $\left(r=0,97^{* *}\right)$, as was the correlation between magnesium uptake and the change in the potassium chloride extractable magnesium of the soil ( $\mathrm{r}$ $\left.=0,96^{* *}\right)$. The plants may have used the "exchangeable" magnesium reserves of the soil as their main source of magnesium.

In a number of pot experiments the plants have been found to utilize small amounts of the magnesium not extractable in neutral ammonium acetate (SALMON and ARNOLD 1963, RICE and KAMPRATH 1968, KAILA and KETTUNEN 1973, SINCLAIR 1981, JOKINEN 1981). The release of "non-exchangeable" magnesium under field conditions may be slow and of such small magnitude that it does not satisfy the magnesium requirements of plants grown under intensive cultivation.

The amount of magnesium released from the soil by treatment with acid (1 M $\mathrm{HCl}, 50^{\circ} \mathrm{C}, 20 \mathrm{~h}$, SCHACHTSCHABEL 1961, KAILA 1973) does not depict the size of the potential reserves of magnesium available to plants. According to KAILA (1973), treatment with acid releases about half of the total amount of magnesium in the topsoil of Finnish mineral soils. Although the amount of this so-called "reserve magnesium" in the soil is large, its importance as regards the uptake of magnesium by plants is, according to the studies carried out by SALMON and ARNOLD (1963) and JERLSTRÖM (1975), insignificant. Therefore there is no reason to carry out acid-extractable magnesium determinations in conjuction with the soil analyses done as part of the advisory service to farmers.

\subsection{Effect of liming on the magnesium available to plants}

Liming increases the cation exchange capacity of the soil (KAILA and RYTI 1968 b, EDMEADES and JUDD 1980, JOKINEN 1981) and thus enhances the ability of the soil to adsorb other cations from the soil solution onto exchange sites. However, it has been found in a number of studies that liming causes part of the magnesium in the soil to be converted into a form not extractable in neutral ammonium acetate (ADAMS and HENDERSON 1962, KAILA 1974, JUO and UZU 1977, EDMEADES and JUDD 1980, GROVE et al. 1981). WIKLANDER and GHOSH (1978) and WIKLANDER (1979) proposed that liming increases the desorption of magnesium and thus caused the leaching of magnesium from limed soils. 
In incubation experiments (JOKINEN $1981 \mathrm{c}$ ), liming reduced the amount of magnesium extracted by different methods in seven mineral soils out of nine. The reduction in the magnesium content was greatest in the case of $0,01 \mathrm{M}$ calcium chloride, and smallest in the case of neutral ammonium acetate (GROVE et al. 1981). Liming slightly increased the amounts of magnesium extracted in different solutions in the case of two sand soils (JOKINEN 1981).

In acid muddy silt and silty clay soils, liming decreased by a slightly smaller amount the potassium chloride $(1 \mathrm{M})$ extractable magnesium in comparison to ammonium acetate extractable magnesium. The extraction ability of unbuffered potassium chloride may be weak in acid soils, but in limed soils it is the same as that of ammonium acetate. In a pot experiment (JOKINEN 1981 a, 1981 b) ryegrass appeared to have taken up approximately the same amount of magnesium from muddy silt as the potassium chloride extractable magnesium content of the soil decreased during the course of the experiment.

\subsection{Effect of the amount of plant available magnesium in the soil on the quantity and nutrient content of the yield}

A decrease in the neutral ammonium acetate extractable magnesium of the soil in the pot experiment, and a decrease in the acid ammonium acetate extractable magnesium in the field experiments only rarely had an effect on the yields of grasses. However, extended exhaustion of the soil magnesium reserves appeared, in the pot experiment, to lead eventually to a decrease in the size of the yield. The first sign of a deficiency in the reserves of plant available magnesium in the soil for grasses appears to be a decrease in the foliage magnesium content, because a yield will even continue to be produced with small magnesium reserves only (JOKINEN 1981 a).

A deficiency of magnesium in the soil first becomes evident in cereals as a reduction in the proportion of the grain yield out of the total yield (SORTEBERG 1974, JOKINEN 1977 a). The weight of the grains which are formed is low (JOKINEN 1977 a, BERING and FORSTER 1981) and maturation of the crops is delayed (SCHARRER and MENGEL 1959, KERÄNEN and JOKINEN 1964). In the final stage the production of grains ceases (JOKINEN 1977 a).

In field experiments, the magnesium uptake by timothy hay increased slightly more clearly $\left(r=0,51^{* *}\right)$ than that of the aftermath $\left(r=0,32^{* *}\right)$ as the magnesium content (acid ammonium acetate extractable) of the soil increased. The magnesium uptake of the cereal grain yield was independent of the magnesium content of the soil (JOKINEN 1978). SALOMON and ARNOLD (1963) found that the magnesium uptake of ryegrass under exhaustive cropping in pot experiments did not initially depend upon the ammonium acetate extractable magnesium content of the soil, and the magnesium uptake decreased only after the magnesium reserves became depleted. The results obtained with coarse mineral soils in pot experiments were similar (JOKINEN 1981 a).

The dependence of the magnesium content of the timothy, harvested as dry hay, on the magnesium content of the soil (acid ammonium acetate, $r=0,65^{* *}$ ) was slightly clearer than that in the same sward at the silage stage $\left(\mathrm{r}=0,41^{* * *}\right)$ or in the aftermath $\left(r=0,43^{* *}\right.$, JOKINEN $\left.1979 \mathrm{a}\right)$. According to the results of a number of other studies the correlation between the magnesium content of the soil and that of grasses is only slight (SEMB 1964, JOKINEN 1969 b, HENRIKSEN 1971, KÄHÄRI and NISSINEN 1978). 
3. Effect of nitrogen and potassium fertilizer levels on the quantity and nutrient content of the yields

\subsection{Quantity of the yield}

Increasing the amount of nitrogen from $50 \mathrm{~kg} / \mathrm{ha}\left(\mathrm{N}_{1}\right)$ to $100 \mathrm{~kg} / \mathrm{ha}\left(\mathrm{N}_{2}\right)$, given annually as calcium nitrate in field experiments, significantly increased the yield of cereals and timothy in almost all the experimental locations in the absence of magnesium fertilization. The increase in the yield of the grass crop (mean 870 f.u./ha) was considerably greater than the increase in the grain yield (mean 100 f.u./ha).

A quadruple level of potassium fertilizer $\left(\mathrm{K}_{4}=240 \mathrm{~kg} / \mathrm{ha} \mathrm{K}\right.$ per year $)$ reduced the grass yield, in comparison to the smaller potassium dosage $\left(\mathrm{K}_{1}=60 \mathrm{~kg} / \mathrm{ha} \mathrm{K}\right)$ by 255 f.u./ha per year, on the average, in field experiments. The negative effect of the largest potassium fertilizer level on the yield was slightly greater at the $\mathrm{N}_{1}$ level than at the $\mathrm{N}_{2}$ level. Increasing the amount of potassium had no significant effect on the size of the cereal grain yields.

In a pot experiment (JOKINEN 1981 a), increasing the amount of nitrogen as ammonium nitrate from $1500 \mathrm{mg} / 4,5$ liter soil $\left(\mathrm{N}_{1}\right)$ to $3000 \mathrm{mg}\left(\mathrm{N}_{2}\right)$ per year in the absense of magnesium fertilization, significantly increased the yield of ryegrass during the first year from all nine mineral soils. The yields in heavy clay and sandy clay during the following years were still significantly greater at the $\mathrm{N}_{2}$ level than at the $\mathrm{N}_{1}$ level right up until the end of the experiment. Increasing the amount of nitrogen in muddy silt and finesand, containing only small amounts of magnesium available to plants, brought about a reduction in the yield during the third year. The total yield obtained during the course of the experiment was almost the same in finesand, muddy silt and silty clays with both levels of nitrogen fertilization.

\subsection{Uptake of magnesium}

The amount of magnesium removed annually in the grass yields (hay + aftermath) increased on the average (mean \pm sd) by $1,8 \pm 0,8 \mathrm{~kg} / \mathrm{ha}$ when the amount of nitrogen was increased from $50 \mathrm{~kg}$ to $100 \mathrm{~kg}$. The amount of magnesium removed in the cereal grains was not significantly increased (JOKINEN 1979 b). The average amount of magnesium removed in the yields (three cereal and two grass yields) during a period of five years was $20,5 \pm 4,9 \mathrm{~kg} / \mathrm{ha}\left(\mathrm{N}_{1}\right)$ or $24,0 \pm 6,5 \mathrm{~kg} / \mathrm{ha}$ $\left(\mathrm{N}_{2}\right)$. This slight increase in the magnesium uptake may be partly caused by the low magnesium content of the soil (less than $100 \mathrm{mg} / \mathrm{l}$ soil of acid ammonium acetate extractable magnesium).

Increasing the amount of nitrogen, given as ammonium nitrate limestone, has been found to increase the magnesium uptake of grasses (e.g. SILLANPÄÄ and RINNE 1975, TÄHTINEN 1979, PENNY et al. 1980). The fact that this type of fertilizer contains magnesium has meant that the depletion of the magnesium reserves of the soil has been only small. In the field experiments carried out by TÄHTINEN (1979), the amount of magnesium derived from the fertilizer was greater than that removed in the yields.

The total amount of magnesium removed by the hay and aftermath yields decreased yearly by $0,9 \pm 1,2 \mathrm{~kg} / \mathrm{ha}$ when potassium fertilization was increased from $60 \mathrm{~kg}$ to $240 \mathrm{~kg}$. The reduction in the amount of magnesium removed was independent of the level of nitrogen fertilizer used. PENNY et al. (1980) found that 
increasing the amount of potassium fertilizer did not reduce magnesium uptake as clearly, when using high levels of fertilizer nitrogen, as was the case with small amounts of fertilizer nitrogen. The effect of a guadruple level of potassium on the amount of magnesium removed in the grain yield $(0,1 \pm 0,2 \mathrm{~kg} / \mathrm{ha} \mathrm{Mg})$ was not significant (JOKINEN 1979 b).

In a pot experiment, ryegrass took up significantly more magnesium from the nine mineral soils, starting from the second cut, when the larger nitrogen fertilization level was used than with the lower level of nitrogen. When the reserves of magnesium available to the plants started to become depleted, the magnesium uptake at both nitrogen levels was almost the same. Furthermore, when cultivation of ryegrass was continued, magnesium uptake remained lower at the higher nitrogen level than at the lower one. If increasing the amount of nitrogen has no effect on magnesium uptake by the plants, then the reduced level of the magnesium reserves in the soil can be considered as limiting the supply of magnesium to the plants.

Under intensive grassland cultivation, the yields may remove $20 \mathrm{~kg} / \mathrm{ha}$ magnesium (=10 mg/100 g soil) annually (HUOKUNA and LAPIOLAHTI 1980). The reserves of magnesium, extractable in neutral ammonium acetate, in the coarse mineral soils of the pot experiment would be sufficient, according to this, for seven years at the most and the magnesium reserves would then be used up completely. The amounts of magnesium taken up from heavy clay and from sandy clays would suffice for 12-24 years and at the end of that time the amount of ammonium acetate extractable magnesium would still not be the growth-limiting factor.

\subsection{Magnesium content of yields}

When there is a deficiency of magnesium, the proportion of the magnesium bound in chlorophyll out of the total amount of magnesium in plants increases (MICHAEL 1941), while at the same time, however, the amounts of chlorophyll, carotene and xanthophyll decrease (PANAK and WOJNOWSKA 1976). None of the other cations can replace the magnesium in chlorophyll. However, the coenzyme role of $\mathrm{Mg}^{2+}$ in a number of enzymatic processes can be replaced for by, for instance, $\mathrm{K}^{+}, \mathrm{Mn}^{2+}, \mathrm{Zn}^{2+}, \mathrm{Cr}^{2+}, \mathrm{Co}^{2+}$ and $\mathrm{NH}_{4}{ }^{+}$(NASON 1958). The deficiency of magnesium in the grain and straw yields of oats grown on Sphagnum peat without magnesium fertilization was found to be partly counteracted by calcium and at the same time an increase in the potassium content was prevented (JOKINEN 1977 b). This result is supported by the results of van ITALLIE (1938), GRIMME et al. (1974) and TERMAN et al. (1975). LEHNE and KOEPKE (1962) did not find that magnesium could be replaced by calcium.

The non-specificity of magnesium as a coenzyme for a number of enzymes means that metabolism can be maintained when there is a deficiency of magnesium. A latent magnesium deficiency may continue for a long time before any deficiency symptoms appear. The ease with which magnesium can be transported from one part of the plant to another together with the flow of metabolic products or water flow is advantageous for the magnesium economy of plants. According to PEASLEE and MOSS (1966), magnesium deficiency only starts to decrease photosynthesis after the deficiency symptoms have already appeared in the plants.

The magnesium content of a grass yield to be used for animal fodder should be at least $2 \mathrm{mg} / \mathrm{g}$ dry-matter (KEMP 1960). Such a level was not reached in the 
timothy yield harvested in field experiments as silage or dry hay when magnesium fertilization was not carried out (JOKINEN 1979 a). The magnesium content of the aftermath, on the other hand, exceeded this level in a number of cases.

Increasing the nitrogen fertilizer level usually increased the magnesium content of grasses despite the fact that the size of the yield also increased (FIEDLER 1960, PENNY et al. 1980). The increase in the magnesium content of the plants caused by fertilization with ammonia nitrogen has usually been smaller than that given by nitrate nitrogen (WOLTON 1960, NOWAKOWKI et al. 1975). Nitrate nitrogen promotes the uptake of cations by plants. HANSEN (1972) found that 12 or 36 day-old barley sprouts grown in soil fertilized with nitrate nitrogen (calcium nitrate) contained more cations than when ammonium nitrogen (ammonium sulphate or urea) was used. According to NIELSEN and CUNNINGHAM (1964), nitrate nitrogen promotes the uptake by ryegrass of divalent cations especially.

In the study carried out by HUOKUNA and LAPIOLAHTI (1980), the magnesium content of the meadow fescue yield harvested for silage was, on the average, $0,20 \%$ of the dry-matter when nitro-chalk or urea was used. The mean magnesium content of yields fertilized with ammonium nitrate limestone was slightly higher $(0,23 \%$ of dry-matter $)$ than the values for the above-mentioned fertilizers, probably as a result of the magnesium content of this type of fertilizer. RINNE et al. (1974) and TÄHTINEN (1979) also observed the increase in the magnesium content of grasses at the silage stage as the ammonium nitrate limestone level is increased.

In a pot experiment, the larger amount of ammonium nitrate (p.a.) produced ryegrass yields with a higher magnesium content than with the smaller nitrogen fertilizer level (JOKINEN 1981 a). When the reserves of magnesium available to the plants started to become exhausted, the magnesium content of the yield obtained with the larger nitrogen fertilizer level remained lower than the magnesium content of the plants which received the smaller amounts of nitrogen. Increasing the amount of nitrogen as calcium nitrate in field experiments, from $50 \mathrm{~kg}$ to $100 \mathrm{~kg}$, significantly increased the magnesium content both of the hay yield and of stand samples taken at the silage stage (JOKINEN 1979 a). On the other hand, the magnesium content of the aftermath decreased and the reduction was clearest in the case of very finesand. Clear symptoms of magnesium deficiency were found in the 4-5-leaf stage of cereal sprouts grown after grass on this soil. These results may indicate that the reserves of magnesium available to plants were low in all soils used in the field experiments. Less than $100 \mathrm{mg} / \mathrm{l}$ soil of acid ammonium acetate extractable magnesium may be too low, for the magnesium content of the aftermath to have remained even the same at both levels of nitrogen fertilizer.

The magnesium content of grass stands harvested many times in succession during the growing season has usually been higher in the last harvests than in the first (WOLTON 1960, JOKINEN 1979 a, PENNY et al. 1980). When the magnesium content of the soil (ammonium acetate extractable) was low, the magnesium content of the last cuts appeared to be lower than that in the first ones (JOKINEN 1979 a, 1981 a).

Increasing the amount of potassium fertilizer from $60 \mathrm{~kg}$ to $240 \mathrm{~kg}$ had no significant effect on the magnesium content of cereal grains in field experiments when magnesium fertilization was not used ( JOKINEN 1979 a). The magnesium content of plant samples taken at different development stages of the grass crop 
decreased significantly. A number of researchers have observed that large levels of potassium fertilizer have a negative effect on the magnesium content of grass stands (e.g. SCHACHTSCHABEL and HOFFMANN 1958, SALONEN and TAINIO 1961, KERÄNEN and TAINIO 1968). According to TÄHTINEN (1979), fertilization with high levels of potassium decreased the magnesium content of the second yield of timothy for silage more than that of the first yield.

\subsection{Equivalent ratios $\mathrm{K} / \mathrm{Mg}$ and $\mathrm{K} /(\mathrm{Ca}+\mathrm{Mg})$ in yields}

Attempts have been made to predict the quality of grass fodder, and also the risk of hypomagneseamie tetany in dairy cattle, by means of the equivalent ratios $\mathrm{K} / \mathrm{Mg}$ and $\mathrm{K} /(\mathrm{Ca}+\mathrm{Mg})$. If the value of the $\mathrm{K} / \mathrm{Mg}$ ratio exceeds 6,0 (JACOBSEN 1969 ) or that of the $\mathrm{K} /(\mathrm{Ca}+\mathrm{Mg})$ ratio exceeds 2,2 (KEMP and t' HART 1957), then the fodder contains too much potassium with respect to the amount of divalent cations.

According to HÅLAND (1971), the $\mathrm{K} /(\mathrm{Ca}+\mathrm{Mg})$ ratio can most effectively be reduced in the early development stage of grass by reducing the potassium content of the stand. The results of the field and pot experiments carried out in this study indicate, however, that raising the calcium content of the stand would reduce the value of the ratio at the silge stage and in the aftermath (JOKINEN 1979 a, MAYLAND et al. 1974), and in the first yield of ryegrass (JOKINEN 1981 a) more markedly than reducing the potassium content would. Changes in the magnesium content of the stands appeared to have a much stronger effect on the $\mathrm{K} / \mathrm{Mg}$ ratio than did changes in the potassium content (JOKINEN 1979 a, 1981 a). The effect of changes in potassium content of the third or fourth yield of ryegrass appeared to be greater than changes in the magnesium content.

In the pot experiment, the larger amount of ammonium nitrate resulted, in the absence of magnesium fertilization, in a significantly lower value for the $\mathrm{K} / \mathrm{Mg}$ ratio at all harvesting times than the smaller amount of nitrogen did (JOKINEN 1981 a). Similar results were also obtained at the silage stage and in the aftermath yield of timothy in the field experiments using calcium nitrate (JOKINEN 1979 a). The $\mathrm{K} /(\mathrm{Ca}+\mathrm{Mg})$ ratio of the grass yield did not change to any significant degree as the amount of nitrogen fertilizer was increased.

A quadruple amount of potassium fertilizer significantly increased the $\mathrm{K} /(\mathrm{Ca}+\mathrm{Mg})$ ratio of the timothy harvested at different development stages in comparison to the value obtained with small amount of potassium (JOKINEN 1979 a).

The $\mathrm{K} / \mathrm{Mg}$ ratio in the timothy yields was independent of the amount of nitrogen applied in nitro-chalk (JOKINEN 1979 a) and in the ryegrass of the amount of nitrogen applied in ammonium nitrate (JOKINEN $1981 \mathrm{a}$ ).

\section{Determination of requirement for magnesium fertilization}

Magnesium fertilization has been shown, in a number of studies (e.g. SCHACHTSCHABEL and HOFFMANN 1958, ALSTON 1966, SORTEBERG 1974), to increase the magnesium content of the plants without, however, having any effect on the yield. The amount of ammonium acetate extractable magnesium in the soil has also increased (BOLTON 1973, MAYLAND and GRUNES 1973), although the magnesium given as easily-soluble magnesium sulphate is rapidly leached away (SEMB 1966). 
The magnesium fertilization requirements were estimated in this study on the basis of the results for the quality and quantity of the yield and the amounts of plant available magnesium in the soil obtained from pot and field experiments with magnesium sulphate.

As well as in the form of magnesium sulphate, magnesium can also be added to the soil in different types of liming agent. The effect of different types of magnesium source is compared in a study based on the results of a pot experiment which will be published later on.

\subsection{Ammonium acetate extractable magnesium in the soil}

Estimates presented for the amount of ammonium acetate extractable magnesium which is sufficient for plants vary considerably. BOLTON and PENNY (1968) proposed, on the basis of field experiments, that $4 \mathrm{mg} / 100 \mathrm{~g}$ soil is sufficient for most plants. According to McLEAN and CARBONELL (1972), magnesium equivalent to $6 \%$ of the cation exchange capacity would be sufficient. If this is the case, then about $7 \mathrm{mg} / 100 \mathrm{~g}$ of soil would be a sufficient amount of magnesium in, for instance, Finnish coarse mineral soils (cation exchange capacity below 10 $\mathrm{me} / 100 \mathrm{~g}$ ). SINCLAIR (1981) came to the conclusion, on the basis of the results of a pot experiment, that the ammonium acetate extractable magnesium level in the soil should be more than $160 \mathrm{mg} / \mathrm{kg}$ of soil. The results of the field and pot experiments carried out in connection with the study in hand appear to be in good agreement with the results of SINCLAIR (1981).

\subsection{Effect of liming on the extractability of fertilizer magnesium in the soil}

In incubation experiments, liming resulted in the conversion of part of the fertilizer magnesium into a form not extractable in neutral ammonium acetate ( $1 \mathrm{M})$, potassium chloride $(1 \mathrm{M})$ or calcium chloride $(0,01 \mathrm{M})$. As the $\mathrm{pH}\left(\mathrm{Ca} \mathrm{Cl}_{2}\right)$ had been increased to between 6,0 and 6,5 magnesium was changed the forms of not extractable compounds in the soil (MOKWUNYE and MELSTED 1973, JUO and UZU 1977). In unlimed soil almost all of the added magnesium was extractable in ammonium acetate after seven weeks incubation. All the magnesium which was added $(4 \mathrm{mg} / \mathrm{l00} \mathrm{g})$ to limed heavy clay and sandy clays was needed to maintain the ammonium acetate extractable magnesium content of the soil at the same level as the unlimed soil.

\subsection{Effect of magnesium fertilization on the yield and magnesium uptake}

The increase in the mean grain yield (68 \pm 105 f.u./ha per year) and grass yield (hay+aftermath, $65 \pm 231$ f.u./ha) obtained with annual applications of magnesium sulphate in field experiments were both modest (JOKINEN 1978). The yield increase obtained at different localities through magnesium fertilization was 1,4$4,1 \%$ of the mean yield obtained without magnesium fertilization. BOLTON and PENNY (1968) also obtained only small yield increases (ryegrass 2,7\%, barley $5 \%$ ) with magnesium fertilization in field experiments.

The yield increases obtained with different magnesium fertilizer levels did not differ significantly from each other even in cases where magnesium fertilization has increased the yield (ALSTON 1966, BOLTON and PENNY 1968, SORTEBERG 1974). It would thus be obvious, from the point of view of the size of the yield, that 
the small amounts of fertilizer magnesium are also effective, if magnesium deficiency is the qrowth limiting factor.

The increase in the grass yield or grain yield obtained with magnesium fertilization ( $57 \mathrm{~kg} / \mathrm{ha} \mathrm{Mg}$ per year) in the field experiments did not appear to be dependent, to any significant degree, on the amount of acid ammonium acetate extractable magnesium in the soil (ley yields: $r=-0,35$, cereal grain yields: $r=-0,11$, JOKINEN 1978). The negative correlation would suggest that the increase in the yield may decrease when the magnesium content of the soil increases. The amount of plant available magnesium in the topsoil may have to be really low before magnesium fertilization is able to increase the yields of cereals and grasses (JERLSTRÖM 1975, BAERUG 1977, JOKINEN 1981 a).

The yield increases obtained with magnesium fertilization at two nitrogen fertilizer levels were not significantly different from each other in field experiments (JOKINEN 1978). A similar result was obtained in the pot experiment with heavy clay and sandy clays. In the case of coarse mineral soils and silty clays, magnesium fertilization only increased the yield when the higher nitrogen fertilizer level was used (JOKINEN 1981 a). In Finland silage grasses are given $200-250 \mathrm{~kg} / \mathrm{ha}$ of nitrogen a year, which is more than twice the amount of nitrogen used in the field experiments of this study. The results of the pot experiment would suggest that magnesium fertilization, together with large amounts of nitrogen, has a beneficial effect on the yield of grasses.

The change in the grass yield obtained by magnesium fertilization appeared to increase when changing from a small amount of potassium ( $-95 \mathrm{f}$.u./ha per year) to a large one ( 225 f.u./ha). The increase in the grain yield of cereals was almost the same with both potassium fertilizer levels (JOKINEN 1978). The requirement of magnesium fertilization would be greater when applying large amounts of potassium and nitrogen to grasslands than when using small amounts of these fertilizers. The increased need for magnesium fertilization when using large amounts of potassium has been evident in pot experiments carried out by, for instance, PRINCE et al. (1947), WELTE and WERNER (1963) and JERLSTRÖM (1975). Adding potassium to soil containing low levels of magnesium, or adding magnesium to soil containing low levels of potassium, had no effect on the hay yield in field experiments carried out by KERÄNEN and TAINIO (1967). Planning fertilization on the basis of the nutrient status of the soil would appear to be pertinent in a number of cases.

Magnesium fertilization increased the magnesium uptake of cereal grain yields by only $0,3 \pm 0,1 \mathrm{~kg} / \mathrm{ha}$ per year $(9 \%)$ and the magnesium uptake of grass yields by $2,1 \pm 1,2 \mathrm{~kg} / \mathrm{ha}(24 \%$, JOKINEN $1979 \mathrm{~b})$. Over a five year period the magnesium uptake increased by a total of $4,6 \pm 1,3 \mathrm{~kg} / \mathrm{ha}$. The magnesium uptake increased the most in the case of muddy very finesand $(8,9 \mathrm{~kg} / \mathrm{ha}, 32 \%)$.

In pot experiments the magnesium uptake of ryegrass growing on coarse mineral soils was increased by magnesium fertilization at both levels of nitrogen fertilization, but on silty clays only at the higher nitrogen fertilizer level. Magnesium fertilization on heavy clay and sandy clays did not increase magnesium uptake at either nitrogen fertilizer levels (JOKINEN 1981 a). The increase in magnesium uptake associated with magnesium fertilization was, in the field experiments, independent of the amount of potassium fertilizer (JOKINEN 1979 b). BEDI and SEKHON (1977) 
observed that magnesium uptake by maize was increased by magnesium fertilization on the soils with a low potassium content to the same extent at all potassium fertilizer levels. Magnesium fertilization increased the magnesium uptake on the soils with a high potassium content by an increasing amount, the greater the amount of potassium fertilizer given.

An increase in magnesium uptake by the plants as a result of magnesium fertilization may indicate the requirement for magnesium fertilization at an earlier stage than an increase in the size of the yield does, because the plants are able to produce a yield even if the magnesium reserves in the soil are low.

\subsection{Apparent recovery of fertilizer magnesium}

The apparent recovery of fertilizer magnesium at seven different locations in the field experiments varied from $0,4 \%$ to $3,1 \%$ (mean $1,6 \pm 0,9 \%$ ). The grain yields removed $0,5 \pm 0,2 \%$ and the grassland yields $3,7 \pm 0,1 \%$ of the fertilizer magnesium annually. In the field experiments carried out by McNAUGHT et al. (1968) the grass yields removed $5-7,5 \%$ and the cereals and grasses in JAAKKOLA and VOGT's (1978) experiments removed 1,7\%. BOLTON and PENNY (1968) and JOKINEN (1977 c) found that there are great differences in the ability of types of plants to utilize the fertilizer magnesium.

The apparent recovery of fertilizer magnesium appeared to be greater in pot experiments at the higher nitrogen fertilizer level than at the lower one (JOKINEN $1981 \mathrm{a}$ ). In the field experiments the effect of the nitrogen level on the recovery of fertilizer magnesium varied at different experimental sites (JOKINEN 1979 b). According to PRINCE et al. (1947), a high level of recovery of fertilizer magnesium indicates that there is a need for magnesium fertilization. On the basis of this, plants growing in a pot experiment on silty clay, as well as on coarse mineral soils, benefitted from magnesium fertilization when large amounts of nitrogen were used.

The apparent recovery of fertilizer magnesium on mull soil and on peat soil was higher at the large potassium fertilizer level in the field experiments than at the small one (JOKINEN 1979 b), because the addition of potassium level significantly increased the yield increase obtained with magnesium fertilization.

\subsection{Effect of magnesium fertilization on the nutrient contents of yields}

Magnesium fertilization significantly increased the magnesium content of the grass yields at all cuts in both the pot (JOKINEN 1981 a) and field experiments (JOKINEN 1979 a), with the exception of the crops grown on heavy clay and sandy clays. The quantitative and relative increase in the magnesium content were greatest in the field experiments at the silage stage. In the studies carried out by BOLTON and PENNY (1968), in which the yields were harvested four times during the same growing season, magnesium fertilization appeared to increase the magnesium content of the last yield more clearly than that of the first yield. The magnesium content of ryegrass showed a similar trend in the pot experiment (JOKINEN 1981 a).

The annual magnesium fertilization did not increase the magnesium content of the grassland yield harvested as dry hay to anywhere near the level mentioned by KEMP (1960), namely $2 \mathrm{mg} / \mathrm{g}$ dry-matter. The magnesium content of stands receiving magnesium fertilization increased at the silage stage and in the aftermath to above $2 \mathrm{mg} / \mathrm{g}$ in a number of experiments. The increase in magnesium content of 
grasses brought about by magnesium fertilization may be less than that for dicotyledenous plants (McNAUGHT et al. 1968).

The variations in the magnesium content of stands in different years were large in the ryegrass yields of the pot experiment, and magnesium fertilization did not even out such differences in the yields obtained from clay soils. The magnesium content of the stands growing on coarse mineral soils decreased as the reserves of plant available magnesium in the soil diminished. Magnesium fertilization evened out this annual variation in the magnesium content.

When large amounts of nitrogen fertilizer were used, magnesium fertilization appeared to increase the magnesium content of the ryegrass at all harvestings to a relatively greater extent than when small amounts of nitrogen were applied (JOKINEN $1981 \mathrm{a})$. Adding nitrogen and magnesium either together or separately had a positive effect on the magnesium content of the stads (PENNY et al. 1980). The relative increase in the magnesium content of timothy caused by magnesium fertilization in field experiments at the silage stage and in the aftermath was slightly greater at the $\mathrm{N}_{1}$ level than at the $\mathrm{N}_{2}$

Magnesium fertilization increased the magnesium content of timothy at the silage stage and in the hay yield at both potassium fertilizer levels, almost just as efficiently in both absolute and relative terms. The magnesium content of the aftermath was increased to a significantly greater extent at the low potassium fertilizer level than at the higher level (JOKINEN 1979 a).

The change in the magnesium content of the grain yield of cereals brought about by magnesium fertilization was only slight (JOKINEN 1979 a). However, there appeared to be considerable variation in the magnesium content of the grains obtained at the different experimental sites.

Magnesium deficiency symptoms were observed at the 4-5-leaf stage in the cereal stands growing during the last experimental year on muddy very finesand in the absence of magnesium fertilization. The weak correlation $(r=0,24)$ between the magnesium content of the sprouts and the grain yield indicates, however, that it is not possible to make predictions about the size of the grain yield on the basis of the magnesium content of the sprouts or on observed symptoms of magnesium deficiency. JERLSTRÖM (1975) came to the same conclusion about the prediction value of the magnesium content of samples taken from cereal stands at the onset of flowering.

Magnesium fertilization significantly decreased the calcium content of the grassland yields at the silage stage and in the hay, but not in the aftermath (JOKINEN 1979 a). The reduction in the calcium content of ryegrass growing in the pot experiment on different mineral soils was not as clear as that found by SCHACHTSCHABEL and HOFFMANN (1968) or HÅLAND (1971) in their experiments. Magnesium fertilization decreased the calcium content of the stands in pot and field experiments independently of the amount of nitrogen or potassium fertilizer applied.

Changes in the $\mathrm{K} / \mathrm{Mg}$ ratio of ryegrass in the pot experiment or of the timothy in the field experiments appeared to be significantly dependent on the variation in the magnesium content of the stands. In the pot experiment magnesium fertilization decreased the ratio value of the yield at all harvestings, and fertilization appeared to have a significant positive effect on the quality of the yields harvested on coarse mineral soils in particular. 
The $\mathrm{K} /(\mathrm{Ca}+\mathrm{Mg})$ ratio of the grassland yields in the field experiments, or of the ryegrass in the pot experiment, were not significantly reduced by magnesium fertilization apart from a few exceptions. The reduction in the calcium content and the increase in the magnesium content caused by magnesium fertilization maintained the sum of divalent cations at the same level, and magnesium fertilization did not change the potassium content of the stands.

\section{Conclusions}

The magnesium of the soil extractable in neutral or acid ammonium acetate appears to be the main source of magnesium for plants. The ammonium acetate (1 $\mathrm{M}, \mathrm{pH}$ 7) extractable magnesium content of soil under intensive grassland cultivation should be about $15 \mathrm{mg} / 100 \mathrm{~g}$ soil. As plants also take up nutrients from the soil below the topsoil, the magnesium content of the subsoil may have a decisive role when estimating the magnesium fertilization requirements.

Conversion of part of the fertilizer magnesium, or magnesium already present in the soil, into a form not extractable in neutral ammonium acetate as a result of liming should be taken into account on soils containing only small amounts of extractable magnesium. The equivalent ratio of ammonium acetate extractable calcium to magnesium in soil may indicate what the ratio of these two cations in the liming agents should be in order to change the nutrient status of the soil and the $\mathrm{Ca} / \mathrm{Mg}$ ratio to a more favorable position.

Cereals appear to be able to produce yields on soils with a relative low magnesium content (acid ammonium acetate). The first signs of a lack of magnesium appear to be magnesium deficiency symptoms in the sprouts or a reduction in the proportion of the grain yield out of the total yield. As far as grasses are concerned, a lack of magnesium in the soil may first become apparent as a strong reduction in the magnesium content or magnesium uptake.

Magnesium fertilization appeared to increase the magnesium content of grasses only slightly. The only possible way of clearly increasing the magnesium content of the yields appears to be the cultivation of mixed clover-grass leys. The effect of magnesium fertilization on the magnesium content of grasses at the silage stage and in the aftermath would appear to be more effective than the effect on the magnesium content of the dry hay.

Increasing the nitrogen fertilizer level significantly increased the magnesium content and magnesium uptake of grasses when the reserves of plant available magnesium in the soil were sufficient. Magnesium fertilization, in turn, increased the magnesium uptake and magnesium content of the stands when the magnesium reserves in the soil were low.

Fertilization with large amounts of potassium appeared to increase the magnesium fertilizer requirements of grasses, especially in cases where large amounts of nitrogen were also added. The ammonium acetate extractable potassium and magnesium content, as well as their equivalent ratio in the soil, give some indication about what the ratio of these two nutrients should be in fertilization when both these nutrients need to be added. The $\mathrm{K} / \mathrm{Mg}$ in the soil is only of importance in soils with a 
poor nutrient status where the addition of either one of these two nutrients would cause a nutrient imbalance in the soil.

Determining which soil properties have an effect on the adsorption or desorption of magnesium added to the soil would provide additional information from the point of view of magnesium fertilization.

The size of the yield, the magnesium uptake or the magnesium content of the plants did not appear to provide an easily interpretable picture of the magnesium fertilization requirements. The information which is obtained about the magnesium fertilization requirements on the basis of the ammonium acetate extractable magnesium content of the soil is just as reliable as that obtained from the properties of the yields. None of these methods are superior to each other, although determining the magnesium content of the soil is the easiest and quickest to carry out.

\section{References}

ADAMS, F. \& HENDERSON, J.B. 1963. Magnesium availability as affected by deficient and adequate levels of potassium and lime. Soil Sci. Soc. Amer. Proc. 26: 65-68.

ANON. 1976. Jätevesiliete lannoitteeksi ja maanparannusaineeksi. Yhdyskuntien vesi- ja ympäristöprojekti. 12 p. Helsinki.

- 1980 a. Suomen virallinen tilasto III. Maatalouden vuositilasto 78: 1-74. Official statistics of Finland III. Annual statistics of agriculture 78: 1-74.

- 1980 b. Lannoitteiden myynnin jakautuminen maatalouskeskusalueittain lannoitusvuonna 1979-80. Kemira Oy, 2 p., 16 tabl. Helsinki.

ALSTON, A. M. 1966. The influence of $\mathrm{N}$ and $\mathrm{Mg}$ fertilizers and $\mathrm{CaCO}_{3}$ on the absorption of $\mathrm{Mg}$ by oats. J. Agric. Sci. 66: 61-66.

BAERUG, R. 1977. Nitrogen, kalium, magnesium og svovel til eng på S $\phi r-\bigoplus$ stlandet II. Kjemiske analyser av avlingen. Summary: Nitrogen, potassium, magnesium and sulphur fertilization of forage in South-eastern Norway II. Chemical analyses of the forage. Forskn. Fors. Landbr. 28: 549-574.

BEDI, A. S. \& SEKHON, G. S. 1977. Effect of potassium and magnesium application to soils on the drymatter yield and cation composition of maize. J. Agric. Sci. 88: 753-758.

BERING, H. S. \& FORSTER, H. 1981. Einfluss varierter Mg-Ernährung auf Tausenkorngewicht und PFractionen des Gerstenkorns. Z. Pflanzenern. Bodenk. 144: 8-15.

BOLTON, J. 1973. Sources of magnesium for sugar beet, potatoes and wheat grown on an acid sandy soil at Woburn. J. Agric. Sci. 81: $553-555$.

- \& PENNY, A. 1968. The effects of potassium and magnesium fertilizers on yield and composition of successive crops of ryegrass, clover, sugar beet, potatoes, kale and barley on sandy soil at Woburn. J. Agric. Sci. 70: 303-311.

DRAKE, M \& SCARSETH, G. D. 1939. Relative abilities of different plants to absorb potassium and the effects of different levels of potassium on the absorption of calcium and magnesium. Soil Sci. Soc. Amer. Proc. 4: 201-204.

_ , VENGRIS, J. \& COLBY, W. G. 1951. Cation-exchange capacity of plant roots. Soil Sci. 72: 139147.

EDMEADES, D. C. \& JUDD, M. J. 1980. The effects of lime on magnesium status and equilibria in some New Zealand topsoils. Soil Sci. 129: 156-161.

FARINA, M. P. V., SUMNER, M. E., PLANK, C. O. \& LETZSCH, W. S. 1980. Effect of pH on soil magnesium and its absorption by corn. Comm. Soil Sci. Plant Anal. 11: 981-992.

FIEDLER, H. J. 1960. Über die Beziehungen zwischen Stickstoff und Magnesium bei Weidelgras. Z. landw. Versuchs-. Unters. wesen 6: 419-428.

GRIMME, H., BRAUNSCHWEIG, L. C. von \& NÉMETH, K. 1974. Beziehungen zwischen Kalium, Calcium und Magnesium bei Aufnahme und Ertragsbildung. Landw. Forsch. Sonderh. 30/11: $93-$ 100

GROVE, J. H., SUMNER, M. E. \& SYERS, J. K. 1981. Effect of lime on exchangeable magnesium in variable surface charge soils. Soil Sci. Soc. Amer. J. 45: 497-500. 
HANSEN, E. M. 1972. Studies on the chemical composition of isolated soil solution and the cation absorption by plants I. Relationship between form and amount of added nitrogen and absorption of nitrogen, potassium, sodium and magnesium by barley. Plant and Soil 37: 589-607.

HARTIKAINEN, H. 1978. Leaching of plant nutrients from cultivated soil I. Leaching of cations. J. Scient. Agric. Soc. Finl. 50: 263-269.

HEINONEN, R. 1956. Magnesiumin tarpeesta Suomen pelloissa. Summary: Magnesium requirements in Finnish agriculture. Agrogeol. Julk. 65: 1-32.

HENRIKSEN, A. 1970. Magnesiumbalancen i danske landbrugsjorder. Summary: The magnesium balance in Danish agricultural soils. Tidsskr. Planteavl 74: 224-233.

- 1971. Om tilgaengeligheden af jordens magnesiumreserver. Summary: On the availability of magnesium reserves in soil. Tidsskr. Planteavl 75: 647-663.

HOLMA, M. 1981. Esitutkimus lannan hyväksikäytöstä. Suomen Itsenäisyyden 1967 Rahasto. 65 p. Helsinki.

HUOKUNA, E. \& LAPIOLAHTI, J. 1980. Different nitrogen fertilizers on meadow fescue ley. Ann. Agric. Fenn. 19: 125-130.

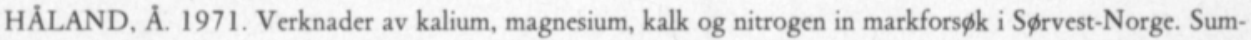
mary: Effects of potassium, magnesium, lime and nitrogen in field experiments in south-western Norway. Forskn. Fors. Landbr. 22: 1-20.

ITALLIE, T. B. van. 1937. Magnesiummangel und Ionenverhältnisse in Getreidepflanzen. Bodenk. Pflanzenern. 5: 303-334.

- 1938. Cation equillibra in plants in relation to the soil. Soil Sci. 46:175-186.

JAAKKOLA, A. \& JOKINEN, R. 1980. Comparison of fine and coarse limestones in pot and field experiments. Ann. Agric. Fenn. 19: 108-124.

- \& VOGT, P. 1978. The effect of mineral elements added to Finnish soils on the mineral contents of cereals, potato, and hay crop I. Calcium, magnesium, phosphorus, potassium, copper, iron, manganese, sodium and zink. Acta Agric. Scand. Suppl. 20: 53-68.

JACOBSEN, A. 1969. Fors $\phi g$ med stigende maengder kalig $\phi$ dning til klфvergraes 1965-1969. Beretning om faellesfors $\phi \mathrm{g}$ i Landbo- og Husmandsforeningerne 1969: 180-183. (Ref. Klausen, P. S. \& Larsen, K. E. 1977.)

JERLSTRŌM, H-G. 1975. Studier över möjligheterna att med växt- och jordanalyser beskriva magnesiumsituationen i svensk vãxtodling. Summary: Studies on the magnesium situation in Swedish agriculture using soil and plant analysis. 197 p. Diss.

JOKINEN, R. 1969 a. The influence of clover content of mixed ley on magnesium and potassium in red clover and timothy. J. Scient. Agric. Soc. Finl. 41: 3-11.

- $1969 \mathrm{~b}$. The magnesium status of soil and the magnesium content of cultivated plants. J. Scient. Agric. Soc. Finl. 41: 290-297.

- 1971. Magnesiumlannoituksen vaikutus satoihin ja maahan. Referat: Magnesiumgödslingens skördeeffekt. Kehittyvã Maatalous 2: 11-18.

- 1977 a. Effect of added magnesium, potassium, lime and nitrogen on oats I. Yields. J. Scient. Agric. Soc. Finl. 49: 283-295.

- 1977 b. Effect of added magnesium, potassium, lime and nitrogen on oats II. Nutrient contents, cation ratios and magnesium uptake. J. Scient. Agric. Soc. Finl. 49: 296-314.

- 1977 c. Magnesiumlannoitus, kalkitus ja runsas kaliumlannoitus. Referat: Magnesiumgödsling, kalkning och riklig kaliumgödsling. Kehittyvä Maatalous 36: 12-25.

- 1978. The effect of magnesium fertilizing on spring cereal and cultivated ley yield and on soil nutrient contents at two potassium and nitrogen fertilizer levels. Ann. Agric. Fenn. 17: 192-204.

- 1979 a. The effect of magnesium, potassium and nitrogen fertilizers on the contents and ratios of nutrients in spring cereals and grassland crops. Ann. Agric. Fenn. 18: 188-202.

- $1979 \mathrm{~b}$. The effect of magnesium, potassium and nitrogen on the uptake of nutrients by spring cereals and cultivated grassland. Ann. Agric. Fenn. 18: 203-212.

- 1981 a. Soil magnesium and fertilizer magnesium uptake by ryegrass on nine mineral soils at two ammonium nitrate levels I. Magnesium uptake. Ann. Agric. Fenn. 20: 231-243.

- 1981 b. Soil magnesium and fertilizer magnesium uptake by ryegrass on nine mineral soils at two ammonium nitrate levels II. Magnesium content of soils. Ann. Agric. Fenn. 20: 244-252

- 1981 c. Effect of liming on the magnesium status on some mineral soils and on the fate of fertilizer magnesium. J. Scient. Agric. Soc. Finl. 53: 126-137. 
JOY, P., LAKANEN, E. \& SILLANPÄÄ, M. 1973. Effects of heavy nitrogen dressings upon release of potassium from soils cropped with ley grasses. Ann. Agric. Fenn. 12: 172-184.

JUO, A. J. R. \& UZU, F. O. 1977. Liming and nutrient interactions in two ultisols from southern Nigeria. Plant and Soil 47: 419-430.

JØRGENSEN, V. 1978. Luftens og nedbørens kemiske sammansaetning i danske landområder. Summary: Chemical composition of air and precipitation in Danish agricultural areas. Tidsskr. Planteavl 82:633656.

KAILA, A. 1972. Basic exchangeable cations in Finnish mineral soils. J. Scient. Agric. Soc. Finl. 44: $164-170$.

- 1973. Calsium, magnesium and potassium in mineral soils from southern half of Finland. J. Scient. Agric. Soc. Finl. 45: 62-83.

- 1974. Effect of liming on basic exchangeable cations of soil. J. Scient. Agric. Soc. Finl. 46: 167-174.

- \& KETTUNEN, H. 1973. Magnesium-supplying power of some Finnish mineral soils. J. Scient. Agric. Soc. Finl. 45: 319-324.

- \& RYTI, R. 1968 a. Calcium, magnesium and potassium in clay, silt and fine sand fractions of some Finnish soils. J. Scient. Agric. Soc. Finl. 40: 1-13.

- \& RYTI, R. 1968 b. Effect of application of lime and fertilizers on cultivated peat soil. J. Scient. Agric. Soc. Finl. 40:133-141.

KEMP, A. 1960. Hypomagnesaemia in milking cows. The response of serum magnesium to alterations in herbage composition resulting from potash and nitrogen dressings on pasture. Neth. J. Agric. Sci. 8: 281304.

- \& t'HART, M. L. 1957. Grass tetany in grazing milking cows. Neth. J. Agric. Res. 5: 4-17.

KERÄNEN, T. 1966. Karjanlannan kasvinravinteet. Zusammenfassung: Pflanzennährstoffe im Stallmist. Maatalous ja Koetoiminta 20: 7-13.

- \& JOKINEN, R. 1964. Magnesiumin puutteen torjuminen magnesiumpitoisuudeltaan erilaisilla kalkkikivijauheilla. Referat: Bekämpfung von Magnesiummangel mit Kalksteinmehlen verschiedenen Magnesiumgehaltes. Ann. Agric. Fenn. 3: 244-255.

- \& TAINIO, A. 1967. Kali-magnesiumlannoituskokeiden tuloksia. Zusammenfassung: Ergebnisse von Versuchen mit Kali-Magnesiumdüngung. Maatalous ja Koetoiminta 21: 34-41.

- \& TAINIO, A. 1968. Hiesu- ja savimaiden kalilannoitustarpeesta. Zusammenfassung: Über den Kalidüngungsbedarf von Lehm- und Tornböden. Ann. Agric. Fenn. 7: 161-174.

KLAUSEN, P. S. \& LARSEN, K. E. 1977. Kvaelstof, kalium og magnesium til klфvergraes. Summary: Nitrogen, potassium and magnesium to clover grass. Tidsskr. Planteavl 81: 203-214.

KÄHÄRI, J. 1974. Lietelannan kasvinravinnepitoisuuksista. Abstract: Plant nutrient content of liquid manure. J. Scient. Agric. Soc. Finl. 46: 215-219.

- \& NISSINEN, H. 1978. The mineral element contents of timothy (Pbleum pratense L.) in Finland I. The elements calcium, magnesium, phosphorus, potassium, chromium, cobolt, copper, iron, manganese, sodium and zink. Acta Agric. Scand. Suppl. 20: 26-39.

LEHNE, I. \& KOEPKE, V. 1962. Die Wirkung verschiedener Stickstofformen auf magnesiumarmen Sandboden. Albrecht-Thaer-Archiv 6: 269-276.

LOEWING, W. F. 1928. Calcium, potassium and iron balance in certain crop plants in relation to their metabolism. Plant Physiol. 3: 261-275.

LOW, A. J. \& ARMITAGE, E. R. 1970. The composition of the leachate through cropped and uncropped soils in lysimeters compared with that of the rain. Plant and Soil 33: 393-411.

LẢG, J. 1969. Noen generelle jordbunnskjemiske problemer i relasjon til nedbørens kjemiske sammansetning. Den Norske Veterinaerforening Medlembl. 21: 117-124.

MARTTILA, U. 1965. Exchangeable cations in Finnish soils. J. Scient. Agric. Soc. Finl. 37: 148-161.

MAYLAND, H. F. \& GRUNES, D. L. 1973. Magnesium concentration in Agropyron desertorum grown on two aridisols fertilized with $\mathrm{Mg}$ and $\mathrm{N}$. Agron. J. 66: 79-82.

- , GRUNES, D. L. \& STUART, D. M. 1974. Chemical composition of Agropyron desertorum as related to grass tetany. Agron. J. 66: 441-446.

MCLEAN, E. O. \& CARDONELL, M. D. 1972. Calcium, magnesium and potassium saturation ratios in two soils and their effects upon yields and nutrient contents of German millet and alfalfa. Soil. Sci. Soc. Amer. Proc. 36: 927-930.

McNAUGHT, K., DOROFAEFF, F. D. \& KARLOVSKY, J. 1968. Effect of magnesium fertilizers and season on levels of inorganic nutrients in a pasture on Hamilton clay loam I. Magnesium and calcium. N. Z. J. Agric. Res. 11: 533-550. 
MENGEL, K. 1979. Ernährung unf Stoffwechsel der Pflanze. S Aufl. 466 p. Stuttgart.

MICHAEL, G. 1941. Über die Aufnahme und Verteilung des Magnesiums und dessen Rolle in den höheren grünen Pflanze. Bodenk. Pflanzenern. 25: 65-210.

MOKWUNYE, A. U. \& MELSTED, S. W. 1973. Magnesium fixation and release in soils of temperate and tropical origins. Soil Sci. 116: 359-362.

NASON, A. 1958. The functions of metals in enzyme systems. Soil Sci. 85: 63-77.

NEALESS, T. F. 1956. Components of the total magnesium content within the leaves of white clover and perennial ryegrass. Nature 177: 388-389.

NIELSEN, K. F. \& GUNNINGHAM, R. K. 1964. The effect of soil temperature and form and level of nitrogen on growth and chemical composition of italian ryegrass. Soil Sci. Soc. Amer. Proc. 28: 213 218.

NOWAKOWSKI, T. Z., BOLTON, J. \& LAZARUS, W. 1975. Effects of form and amount of nitrogen and magnesium fertilizers on the yield and on the inorganic and organic composition of italian ryegrass grown on magnesium deficient soil. J. Sci. Food Agric. 26: 1483-1492.

PANAK, H. \& WOJNOWSKA, T. 1976. The effect of magnesium and various nitrogen forms on the synthesis of pigments and magnesium uptake by cock's foot. J. Polish Soil Sci. 9: 153-159.

PEASLEE, D. E. \& MOSS, D. N. 1966. Photosynthesis in K- and Mg-deficient maize leaves. Soil Sci. Soc. Amer. Proc. 30: 220-223.

PENNY, A., WIDDOWSON, F. V. \& WILLIAMS, R. J. 1980. An experiment begun in 1958 measuring of $\mathrm{N}, \mathrm{P}$ and $\mathrm{K}$ fertilizers on yield and $\mathrm{N}, \mathrm{P}$ and $\mathrm{K}$ contents of grass I. Effects during 1964-67. J. Agric. Sci. 95: 575-582.

PRINCE, A. L., ZIMMERMAN, M. \& BEAR, F. E. 1947. The magnesium-supplying powers of $20 \mathrm{New}$ Jersey soils. Soil Sci. 63: 69-78.

RAININKO, K. 1968. The effects of nitrogen fertilization, irrigation and number of harvestings upon leys established with various seed mixtures. Acta Agric. Fenn. 112: 1-137.

RANKAMA, K. \& SAHAMA, T. G. 1964 Geochemistry. Sth Ed. 912 p. Chicago.

RICE, H. B. \& KAMPRATH, E. J. 1968. Availability of exchangeable and nonexchangeable $\mathrm{Mg}$ in sandy Coastal Plain soils. Soil Sci. Soc. Amer. Proc. 32: 386-388.

RINNE, S-L., SILLANPÄÄ, M., HUOKUNA, E. \& HIIVOLA, S-L. 1974. Effects of heavy nitrogen fertilization on potassium, calcium, magnesium and phosphorus contents in ley grasses. Ann. Agric. Fenn. 13: 96-108.

SALMON, R. C. \& ARNOLD, P. W. 1963. The uptake of magnesium under exhaustive cropping. J. Agric. Sci. 61 : $421-425$.

SALONEN, M. \& TAINIO, A. 1961. Kaliumlannoitusta koskevia tutkimuksia. Summary: Investigations on potash fertilization. Valt. Maatal. koetoim. Julk. 185: 1-60.

- TAINIO, A. \& TÄHTINEN, H. 1962. Typpilannoitusta koskevia tutkimuksia. Summary: Investigations on nitrogen fertilization. Ann. Agric. Fenn. 1:133-174.

SCHACHTSCHABEL, P. 1954. Das pflanzenverfügbare Magnesium des Bodens und seine Bestimmung. $\mathbf{Z}$. Pflanzenern. Düng. Bodenk. 67: 9-23.

- 1961. Fixierung und Nachlieferung von Kalium- und Ammonium-Ionen - Beurteilung und Bestimmung des Kalium-Versorgungsgrades von Böden. Landw. Forsch. Sonderh. 15: 29-47.

- \& HOFFMANN, W. E. 1958. Über den Einfluss der Magnesiumdüngung auf den Gehalt an Nährstoffen im westerwoldischen Weidelgras. Z. Pflanzenern. Düng. Bodenk. 83: 225-234.

SCHARRER, K. \& MENGEL, K. 1958. Über den Kalium-Magnesium-Antagonismus bei Mais und Sonnenblumen. Z. Pflanzenern. Düng. Bodenk. 83: 149-162.

SEMB, G. 1964. Studies on some magnesium aspects in Norwegian soils. 8th Int. Congr. Soil Sci. 4: 347355.

- 1966. Årstidsvariationer i jordas innhold av lettopplфselig fosfor, kalium og magnesium. Summary: Seasonal variations in the soil content of readily soluble phosphorus, potassium and magnesium. Forskn. Fors. Landbr. 17: 165-193.

SINCLAIR, A. H. 1981. Availability of magnesium to ryegrass from soils during intensive cropping in the glasshouse. J. Agric. Sci. 96: 635-642.

SILLANPÄÄ, M. \& RINNE, S-L. 1975. The effect of heavy nitrogen fertilization on the uptake of nutrients and on some properties of soils cropped with grasses. Ann. Agric. Fenn. 14: 210-226.

SIPPOLA, J. 1974. Mineral composition and its relation to texture and to some chemical properties in Finnish sudsoils. Ann. Agric. Fenn. 13: 169-234. 
- \& TARES, T. 1978. The soluble content of mineral elements in cultivated Finnish soils. Acta Agric. Scand. Suppl. 20: 11-25.

SORTEBERG, A. 1974. Verkning av magnesium på avlingsstфrrelse og magnesiuminhold ved ulike kalking og ulike nitrogenforbindelser. Summary: The effect of magnesium application on yield and magnesium content as influenced by liming and different nitrogen sources. Forskn. Fors. Landbr. 25: 537-558.

SOVERI, J. 1976. Epäpuhtauslaskeumista Suomessa 1975-76 sadevesilumianalyysien avulla arvioituna. Summary: Fall-out of impurities in Finland in 1975 and 1976 as evaluated on the basis of analyses of rain water and snow. Ympäristö ja Terveys 7: 837-847.

SVANBERG, O. 1971. De svenska skördeprodukternas innehåll av växtnäringsämnen. Stat. Lantbr. kem. Lab. Medd. 37: 1-9.

TERMAN, G. L., ALLEN, S. E. \& BRADFORD, B. N. 1975. Nutrient dilution-antagonism effects in corn and snap beans in relation to rate and source of applied potassium. Soil Sci. Soc. Amer. Proc. 39: 680685.

TÄHTINEN, H. 1979. The effect of nitrogen fertilizer on the potassium requirement of grassland for silage. Ann. Agric. Fenn. 18: 231-245.

WEISE, K. 1972. N-, K-, Ca- und Mg-Auswaschungsverluste aus verschiedenartigen Ackerböden. Archiv Acker- Pflanzenb. Bodenk. 16: 319-328.

WELTE, E. \& WERNER, W. 1963. Potassium-magnesium antagonism in soils and crops. J. Sci. Food Agric. 14: 180-186.

- , WERNER, W. \& NIEDERBUDDE, E. A. 1960. Zur Frage der Magnesium-Dynamik im Boden. Trans. 7 th Int. Congr. Soil Sci. 2: 283-291.

WIKLANDER, L. 1970. Utlakning av näringsnämnen 1. Halter i dräneringsvatten. Summary: Leaching of plant nutrients 1. The contents in drainage water. Grundförbāttring 23: 117-141.

- 1979. Kalkens markeffekt. Summary: The effect of lime on soil. Kungl. Skogs- Lantbr. Akad. Tidskr. Suppl. 13: 49-53.

- \& GHOSH, S. K. 1978. Continuous ion exchange III. The desorption of $\mathrm{Na}_{2} \mathrm{NH}_{4}, \mathrm{Mg}$ and $\mathrm{Ca}$ as influenced by the degree of $\mathrm{Ca}$ saturation in montmorillonite, illite and kaolin. Acta Agric. Scand. 28: 397-403.

— \& HALLGREN, G. 1971. Utlakning av näringsämnen 2. I åkermark vid Märsta och Gammelstorp. Grundförbättring 24: 69-75.

WOLTON, K. M. 1960. Some factors affecting herbage magnesium levels. Proc. 8th Int. Grassland Congr. p. $544-548$.

ẢRESUND, L. 1980. Extraction and solubility of organic matter and its content of $\mathrm{Ca}, \mathrm{Mg}, \mathrm{K}, \mathrm{Fe}, \mathrm{Al}$ and $\mathrm{Si}$ before and after treatment of the soil with a $\mathrm{H}^{+}$-saturated ion-exchange resin. Swed. J. Agric. Res. 10: $139-154$.

Ms received September 25, 1981. 


\title{
Magnesiumlannoituksen tarve Suomessa
}

\author{
Raili Jokinen
}

Helsingin yliopisto, Maanviljelyskemian laitos, 00710 Helsinki 71.

Keskimäärin Suomen viljelymaista poistuu vuosittain magnesiumia satojen mukana $(10 \mathrm{~kg} / \mathrm{ha})$ ja huuhtoutumalla (15-20 kg/ha) enemmän kuin lannoitteissa (4 kg/ha), karjanlannassa ( $7 \mathrm{~kg} / \mathrm{ha})$ ja ilmasta kuivatai märkälaskeumina $(1 \mathrm{~kg} / \mathrm{ha}$ ) tulee maahan magnesiumia. Kalkitusaineissa tulevalla magnesiummäärällä (enintään $25 \mathrm{~kg} / \mathrm{ha}$ ) on ratkaiseva vaikutus maiden magnesiumtaseeseen, vaikka kalkitus vähentääkin maan omien magnesiumvarojen uuttumista neutraaliin ammoniumasetaattiin.

Kahden typpi- tai kahden kaliummäärän vaikutusta kevätviljojen ja nurmiheinien satoon, magnesiumin ottoon ja sadon ravinnepitoisuuksiin samoin kuin kalkituksen vaikutusta maan magnesiumtilaan selviteltiin kenttä-, astia- ja muhituskokein tavoitteena magnesiumlannoituksen tarpeen arvioiminen. Magnesiumsulfaattilannoituksella saatuja tuloksia samoista kokeista käytettiin myös magnesiumlannoituksen tarpeen ilmaisijana.

Maan neutraaliin ammoniumasetaattiin (1 M) uuttuva magnesium nảytti olevan tärkein kasvustojen magnesiumin lähde ja parhain magnesiumlannoituksen tarpeen ilmaisija. Intensiivistã nurmikasvien viljelyã varten maassa tulisi olla noin $15 \mathrm{mg} / 100 \mathrm{~g}$ maata neutraaliin ammoniumasetaattiin uuttuvaa magnesiumia. Koska kasvit ottavat ravinteita muokkauskerroksen alapuoleltakin, pohjamaan magnesiumpitoisuudella saattaa olla ratkaiseva merkitys magnesiumlannoituksen tarvetta arvioitaessa.

Typpilannoitemäärän lisääminen (astiakoe, 4,51 maata: $\mathrm{N}_{1}=1500 \mathrm{mg}, \mathrm{N}_{2}=3000 \mathrm{mg} \mathrm{N}$ vuodessa; kenttäkokeet: $\mathrm{N}_{1}=50 \mathrm{~kg} / \mathrm{ha}, \mathrm{N}_{2}=100 \mathrm{~kg} / \mathrm{ha} \mathrm{N}$ vuodessa) aiheutti yleensä nurmiheinien magnesiumpitoisuuden ja magnesiumin oton lisääntymisen. Karkeissa kivennäismaissa kasvustojen magnesiumpitoisuus ja -otto vähenivät typen määrää lisättäessã toisena ja kolmantena vuotena maiden magnesiumpitoisuuden niukkuuden vuoksi (astiakoe: alle $12 \mathrm{mg} / 100 \mathrm{~g}$ neutraaliin ammoniumasetaattiin uuttuvaa magnesiumia, kenttäkokeet: alle $100 \mathrm{mg} / \mathrm{l}$ happamaan ammoniumasetaattiin uuttuvaa magnesiumia). Magnesiumlannoituksella (200 mg $\mathrm{Mg} 4,5$ litraan mata tai $57 \mathrm{~kg} / \mathrm{ha} \mathrm{Mg}$ vuodessa) näytti olevan näissã maissa positiivinen vaikutus kasvustojen magnesiumin saantiin. Astiakokeen aitosavi ja hietasavet eivät tarvinneet magnesiumlannoitusta. Runsaasti hiesulajitetta $(0,02-0,2 \mathrm{~mm})$ sisältävien hiesusavien ammoniumasetaattiin uuttuva magnesiumpitoisuus lienee liian alhainen intensiivistä nurmiviljelyä varten ja magnesiumlannoitus saattaa olla tarpeen.

Typpilannoitemäärän lisääminen kohotti merkitsevästi heinäkasvien magnesiumpitoisuutta ja -ottoa, jos kasveille käyttökelpoiset magnesiumvarat maassa olivat rïttävät. Magnesiumlannoitus taas kohotti näitä kasvustojen ominaisuuksia, jos maan magnesiumvarat olivat niukat.

Kaliumlannoituksen lisääminen $60 \mathrm{~kg}$ :sta $\left(\mathrm{K}_{1}\right) 240 \mathrm{~kg}$ :aan $\left(\mathrm{K}_{4}\right) \mathrm{K}$ vuodessa pienensi merkitsevästi kasvustojen magnesiumpitoisuutta. Liejuisessa hienossa hiedassa myös timotein sato ja magnesiumin otto vähenivät kaliummääräã lisättảessã. Runsas kaliumlannoitus näytti lisāävän magnesiumlannoituksen tarvetta varsinkin, kun samalla typpilannoitemäärã oli runsas. Ammoniumasetaattiin uuttuvan kaliumin ja magnesiumin pitoisuus sekã näiden ravinteiden ekvivalenttisuhde maassa antavat viitteitä missä suhteessa ravinteita olisi annettava silloin, kun kummankin ravinteen lisääminen on tarpeen. Ekvivalenttisuhteella $\mathrm{K} / \mathrm{Mg}$ maassa on merkitystä vain huonon ravinnetilan omaavilla mailla, jotta jomman kumman ravinteen lisäämisellä ei aiheutettaisi ravinteiden epäsuhdetta maahan.

Kalkitus $\left(90,180\right.$ tai $360 \mathrm{mg} / 100 \mathrm{~g}$ maata $\mathrm{Ca}, \mathrm{CaCO}_{3}$ :na) pienensi yhdeksästä kivennäismaasta seitsemässã neutraaliin ammoniumasetaattiin uuttuvan magnesiumin määräå 2-24 \% kalkitsemattomaan maahan verrattuna. Osa lannoituksena annetustakin magnesiumista muuttui uuttumattomaksi. Niukasti uuttuvaa magnesiumia sisältåvillã mailla kalkituksen aiheuttama magnesiumin muuttuminen ammoniumasetaattiin uuttumattomaksi tulisi ottaa huomioon magnesiumlannoituksen tarpeen lisääjänä. Ammoniumasetaattiin uuttuvien kalsiumin ja magnesiumin ekvivalenttisuhde maassa osoittanee mikä näiden ravinteiden suhde tulisi olla kalkitusaineessa, jotta maan ravinnetilaa ja -suhdetta voitaisiin muuttaa edulliseen suuntaan.

Magnesiumlannoitus nãytti lisäävãn nurmikasvustojen magnesiumpitoisuutta vain lievästi. Ainoa mahdollisuus heinäsadon magnesiumpitoisuuden selvään kohottamiseen lienee apilan ja heinäkasvien sekakasvuston viljely. Säilörehuasteella ja odelmasadossa heinäkasvien magnesiumpitoisuus saattoi kohota magnesiumlannoituksella selvemmin kuin kuivassa heinãsadossa.

Viljat tuottivat satoa suhteellisen alhaisenkin magnesiumpitoisuuden (hapan ammoniumasetaatti) omaavilla mailla. Magnesiumin niukkuuden ensimmäiset ilmaisijat lienevät oraissa todettavat magnesiumin puutteen oireet 
tai jyväsadon osuuden väheneminen kokonaissadosta. Nurmikasvustojen osalta voimakas magnesiumpitoisuuden tai magnesiumin oton vāheneminen osoittanevat ensimmäisenä maan kasveille käyttökelpoisten magnesiumvarojen niukkuutta.

Sadon määrä, kasvustojen magnesiumpitoisuus tai magnesiumin otto eivät nāyttäneet antavan helposti tulkittavaa kuvaa magnesiumlannoituksen tarpeesta. Maan ammoniumasetaattiin uuttuva magnesiumpitoisuus antanee yhtä luotettavan tiedon magnesiumlannoituksen tarpeesta kuin satojen ominaisuudetkin. Mikään näistä tavoista ei ole toistaan parempi, mutta maan ammoniumasetaattiin uuttuvan magnesiumpitoisuuden määrittäminen lienee nopein ja helpoin toteuttaa. 